Prepared in Cooperation with the Sea Duck Joint Venture Continental Technical Team

\title{
Visualizing Populations of North American Sea Ducks: Maps to Guide Research and Management Planning
}

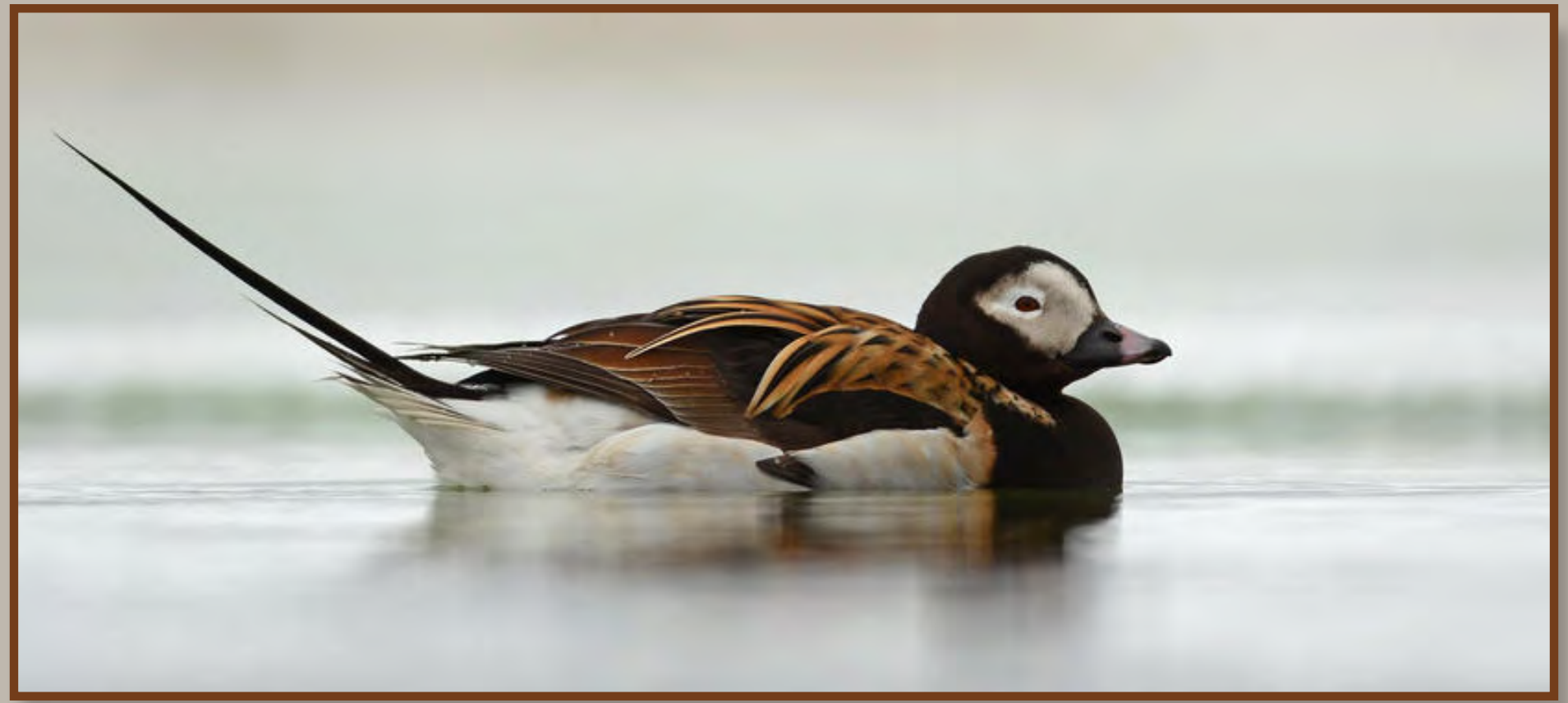

Open-File Report 2019-1142 
Cover: Male long-tailed duck. (Photograph by Ryan Askren, U.S. Geological Survey, public domain.) 


\section{Visualizing Populations of North American Sea Ducks: Maps to Guide Research and Management Planning}

By John M. Pearce, Paul L. Flint, Mary E. Whalen, Sarah A. Sonsthagen, Josh Stiller, Vijay P. Patil, Timothy Bowman, Sean Boyd, Shannon S. Badzinski, H. Grant Gilchrist, Scott G. Gilliland, Christine Lepage, Pam Loring, Dan McAuley, Nic R. McLellan, Jason Osenkowski, Eric T. Reed, Anthony J. Roberts, Myra O. Robertson, Tom Rothe, David E. Safine, Emily D. Silverman, and Kyle Spragens

Open-File Report 2019-1142

U.S. Department of the Interior

U.S. Geological Survey 


\section{U.S. Department of the Interior \\ David Bernhardt, Secretary}

\section{U.S. Geological Survey James F. Reilly II, Director}

U.S. Geological Survey, Reston, Virginia: 2019

For more information on the USGS-the Federal source for science about the Earth, its natural and living resources, natural hazards, and the environment-visit https://www.usgs.gov/ or call 1-888-ASK-USGS (1-888-275-8747).

For an overview of USGS information products, including maps, imagery, and publications, visit https:/store.usgs.gov.

Any use of trade, firm, or product names is for descriptive purposes only and does not imply endorsement by the U.S. Government.

Although this information product, for the most part, is in the public domain, it also may contain copyrighted materials as noted in the text. Permission to reproduce copyrighted items must be secured from the copyright owner.

Suggested citation:

Pearce, J.M., Flint, P.L., Whalen, M.E., and others, 2019, Visualizing populations of North American sea ducks-Maps to guide research and management planning: U.S. Geological Survey Open-File Report 2019-1142, 50 p., https://doi.org/10.3133/ofr20191142.

ISSN 2331-1258 (online) 


\section{Contents}

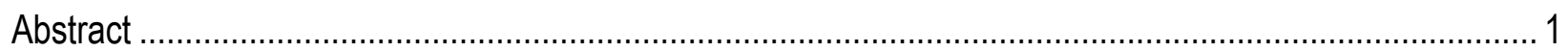

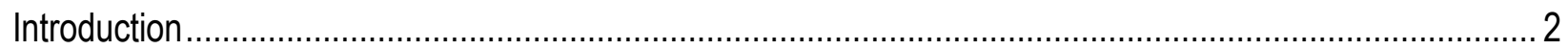



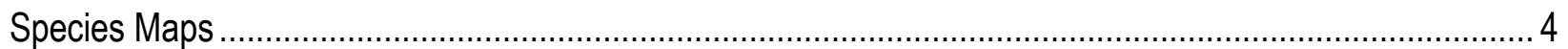

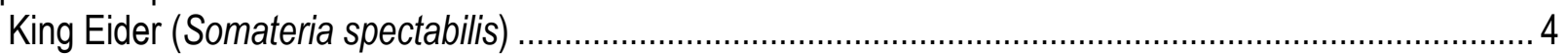

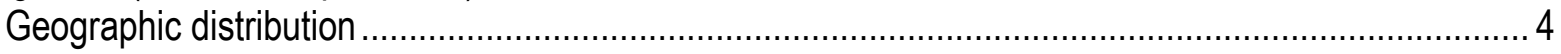

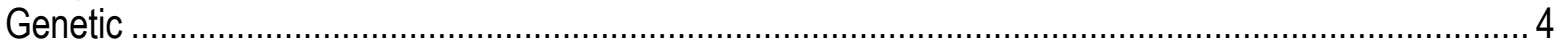

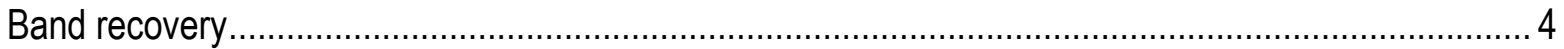

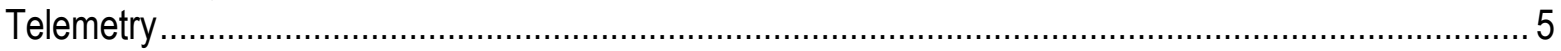

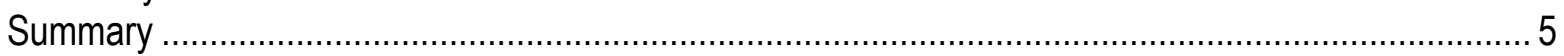

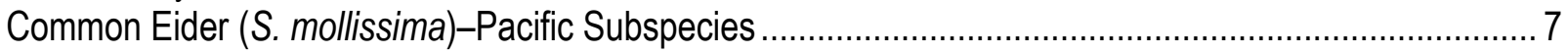

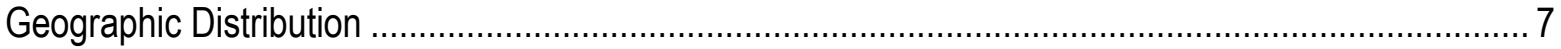

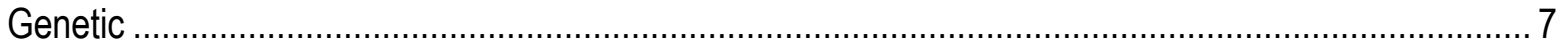



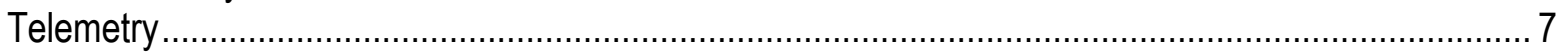



Common Eider (S. mollissima)-Hudson Bay Subspecies ……….............................................. 9

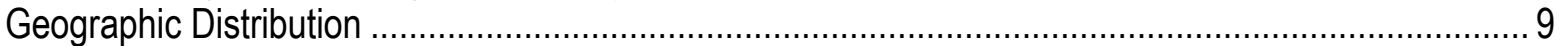



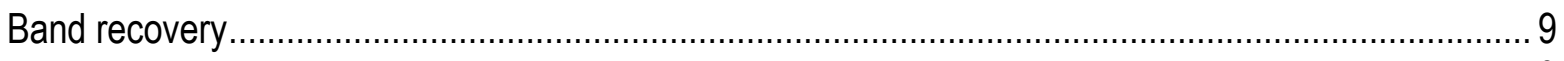

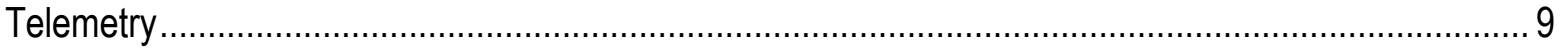



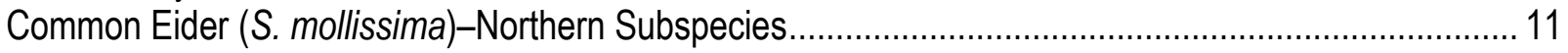

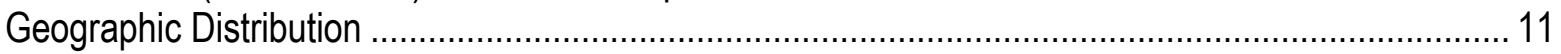



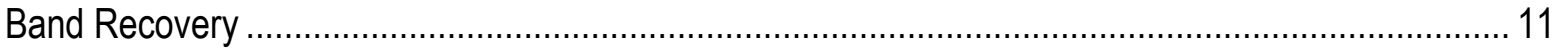

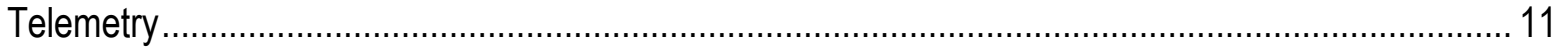

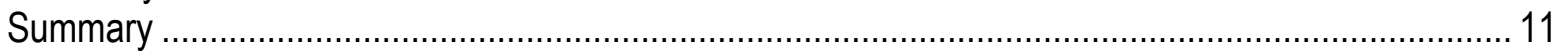

Common Eider (S. mollissima)-American Subspecies ................................................................. 14

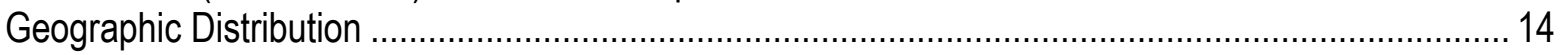

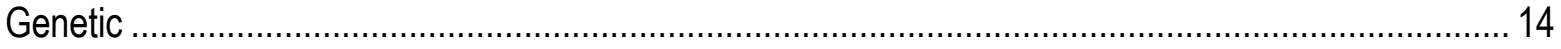

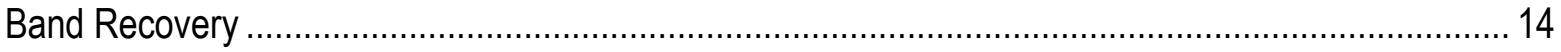

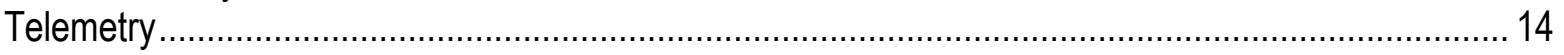

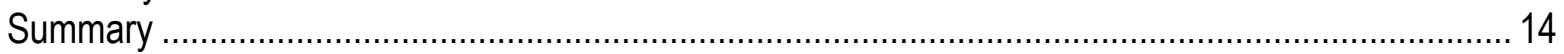

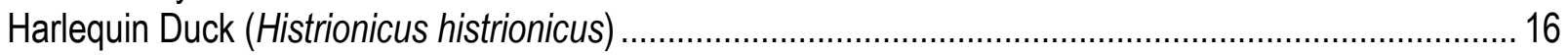

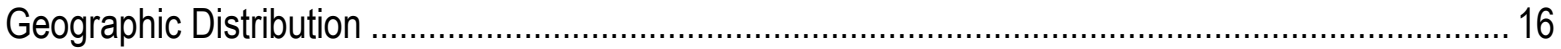

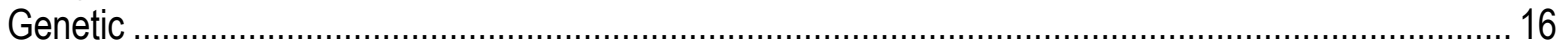

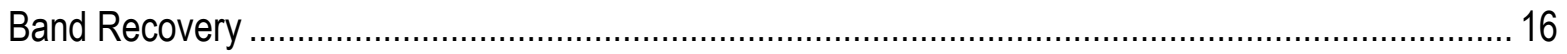

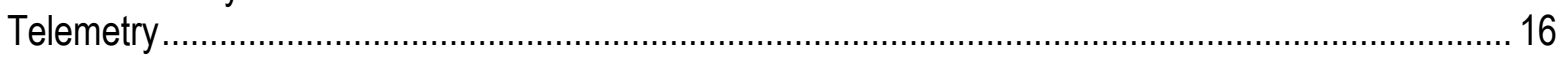





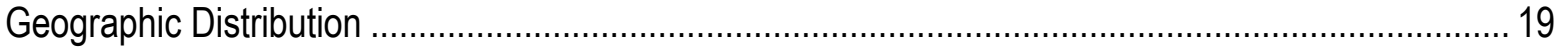

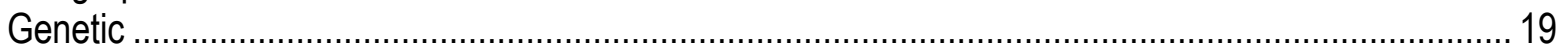

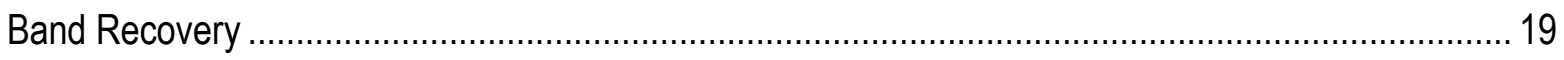

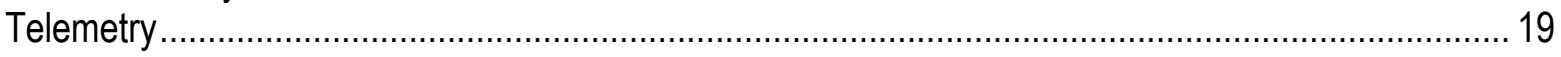










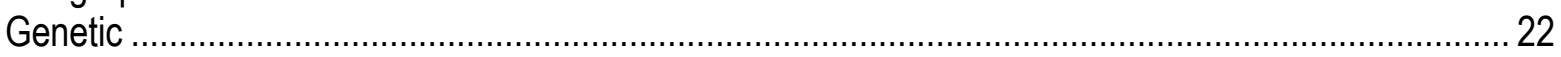

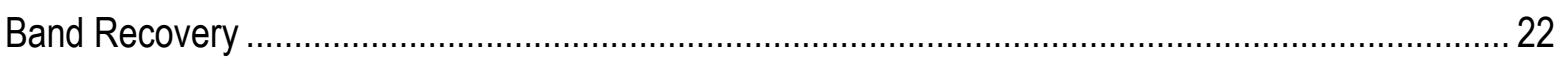

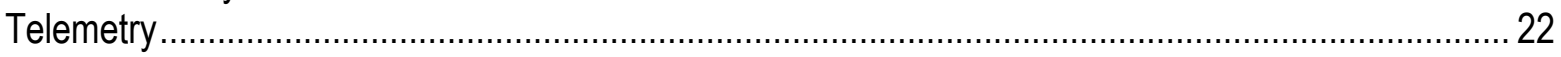



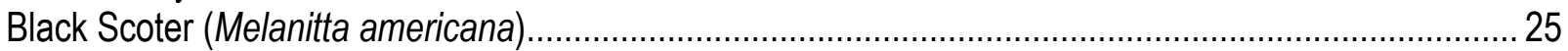

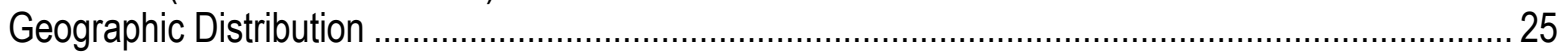

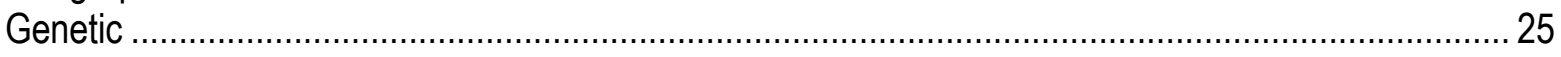

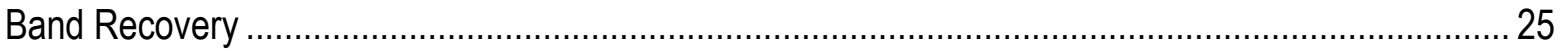



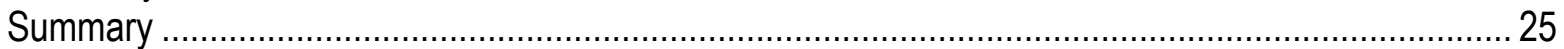

Long-Tailed Duck (Clangula hyemalis) ..................................................................................... 27

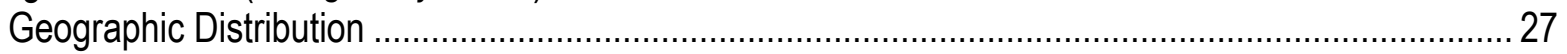

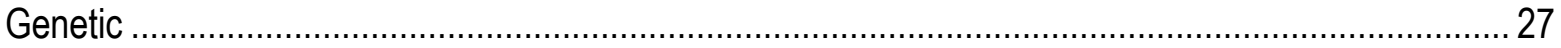

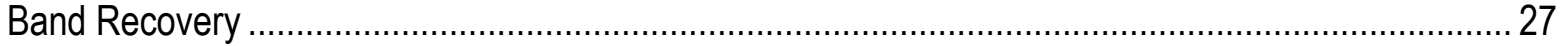

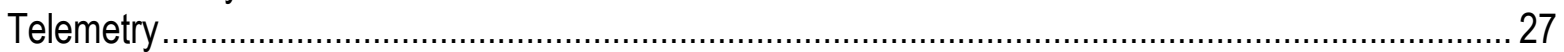

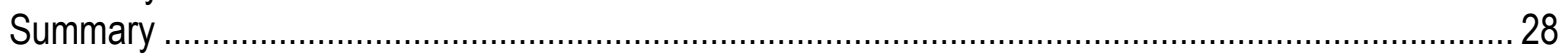

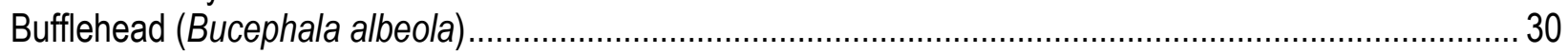

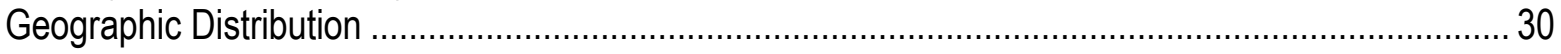

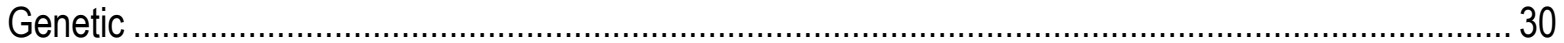

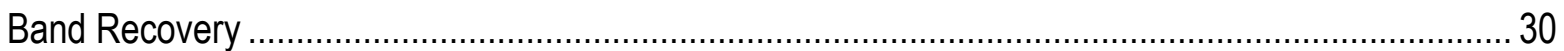

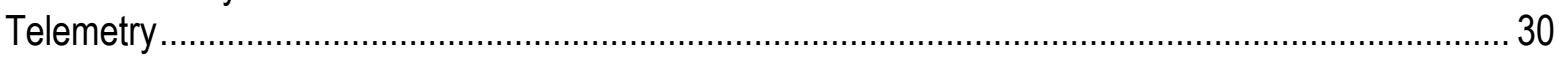

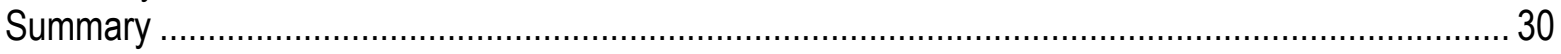

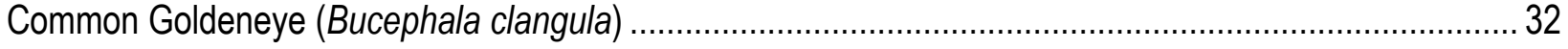

Geographic Distribution ................................................................................................. 32

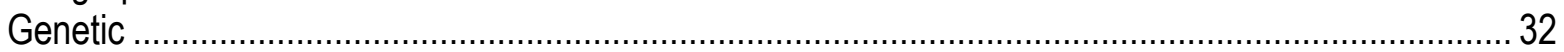

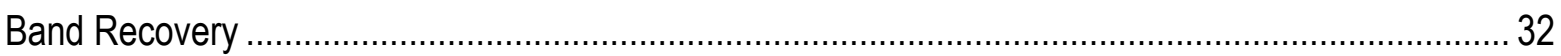

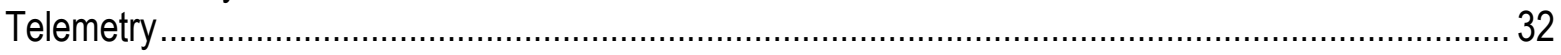

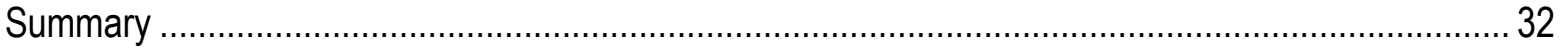



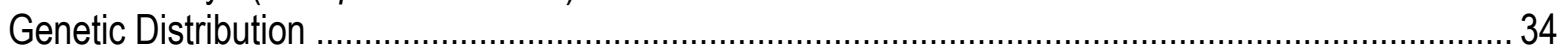

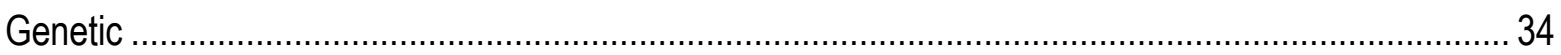

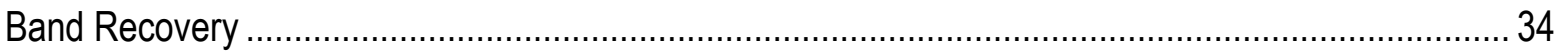

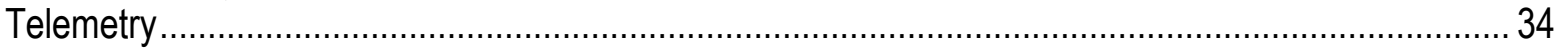

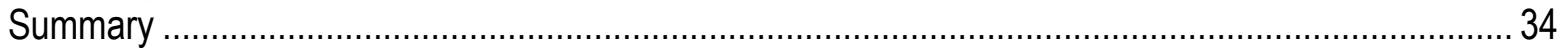

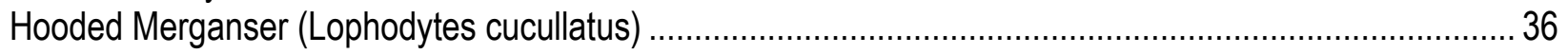

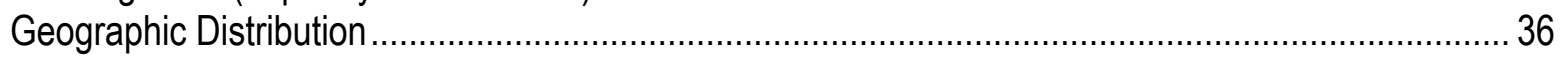

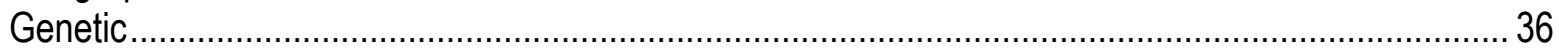

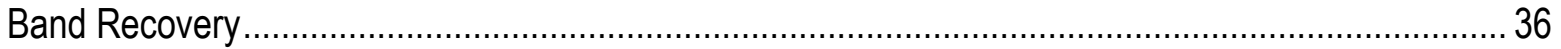

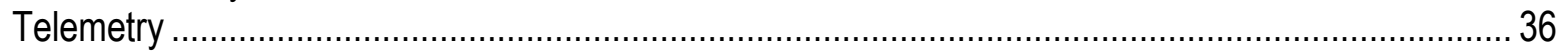

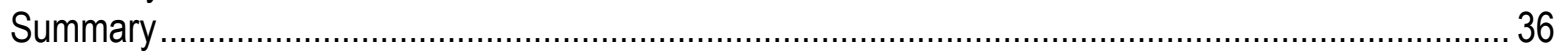

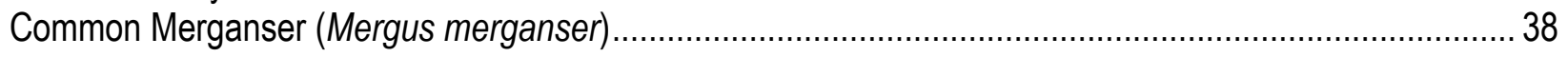

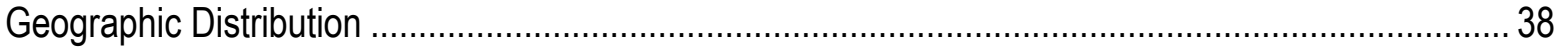

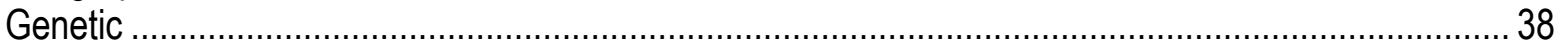

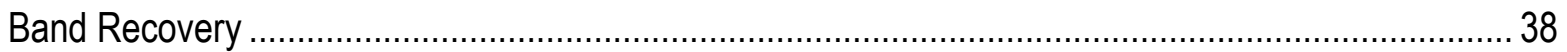






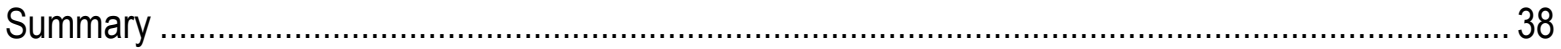

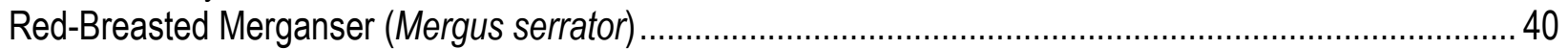

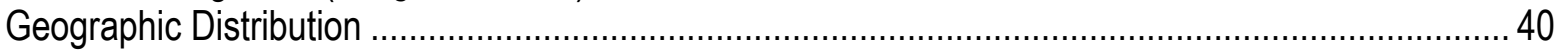



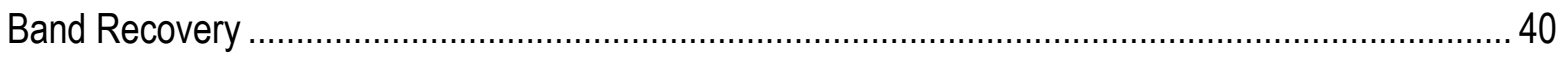

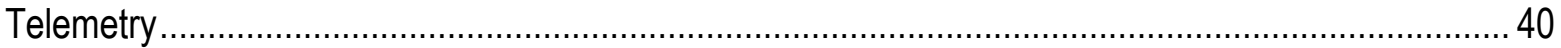

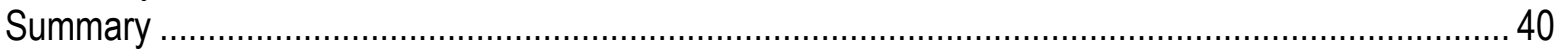

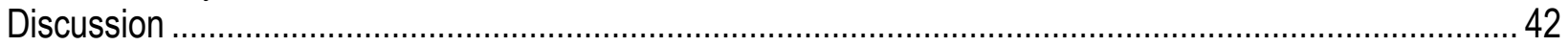



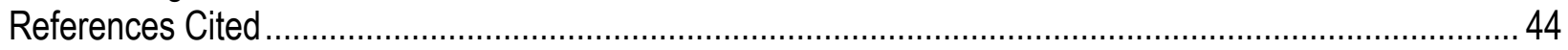

\section{Figures}

Figure 1. Maps showing king eider information from geographic distribution, genetic, band recovery, and telemetry studies across North America and Greenland..................................................................... 6

Figure 2. Map showing common eider information from geographic distribution, genetic, band recovery, and telemetry studies across North America ………………….................................................... 8

Figure 3. Maps showing common eider information from geographic distribution, genetic, band recovery,

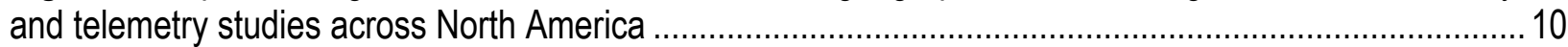

Figure 4. Maps showing common eider information from geographic distribution, genetic, band recovery and telemetry studies across North America. …………………………………………………..... 13 Figure 5. Maps showing common eider information from geographic distribution, genetic, band recovery, and telemetry studies across North America .............................................................................. 15 Figure 6. Maps showing harlequin duck information from geographic distribution, genetic, band recovery, and telemetry studies across North America

Figure 7. Maps showing surf scoter information from geographic distribution, genetic, band recovery, and telemetry studies across North America

Figure 8. Map showing white-winged scoter information from geographic distribution, genetic, band recovery, and telemetry studies across North America..................................................................... 24 Figure 9. Maps showing black scoter information from geographic distribution, genetic, band recovery, and telemetry studies across North America ......................................................................................... 26 Figure 10. Maps showing long-tailed duck information from geographic distribution, genetic, band recovery,

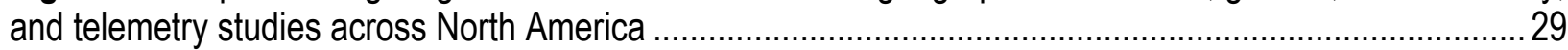
Figure 11. Maps showing bufflehead information from geographic distribution, genetic, band recovery, and telemetry studies across North America. Molting locations are not shown ............................................ 31 Figure 12. Maps showing common goldeneye information from geographic distribution, genetic, band recovery, and telemetry studies across North America.

Figure 13. Maps showing Barrow's goldeneye information from geographic distribution, genetic, band recovery, and telemetry studies across North America.

Figure 14. Maps showing hooded merganser information from geographic distribution, genetic, band recovery, and telemetry studies across North America.

Figure 15. Maps showing common merganser information from geographic distribution, genetic, band recovery, and telemetry studies across North America.

Figure 16. Maps showing red-breasted merganser information from geographic distribution, genetic, band recovery, and telemetry studies across North America. 


\title{
Visualizing Populations of North American Sea Ducks: Maps to Guide Research and Management Planning
}

\author{
By John M. Pearce, ${ }^{1}$ Paul L. Flint, ${ }^{1}$ Mary E. Whalen, ${ }^{1}$ Sarah A. Sonsthagen, ${ }^{1}$ Josh Stiller, ${ }^{2}$ Vijay P. Patil, ${ }^{1}$ \\ Timothy Bowman, ${ }^{3}$ Sean Boyd, ${ }^{4}$ Shannon S. Badzinski, ${ }^{5}$ H. Grant Gilchrist, ${ }^{5}$ Scott G. Gilliland, ${ }^{6}$ Christine \\ Lepage, ${ }^{7}$ Pam Loring, ${ }^{8}$ Dan McAuley, ${ }^{9}$ Nic R. McLellan, ${ }^{10}$ Jason Osenkowski, ${ }^{11}$ Eric T. Reed, ${ }^{12}$ Anthony J. \\ Roberts, ${ }^{13}$ Myra O. Robertson, ${ }^{12}$ Tom Rothe, ${ }^{3}$ David E. Safine, ${ }^{3}$ Emily D. Silverman, ${ }^{13}$ and Kyle Spragens ${ }^{14}$
}

\begin{abstract}
North American sea ducks generally breed in mid- to northern-latitude regions and nearly all rely upon marine habitats for much of their annual cycle. Most sea duck species remained poorly studied until the 1990s when declines were noted in several species and populations. Subsequent research, much of which was funded by the Sea Duck Joint Venture, began in the late 1990s with an emphasis on defining use areas throughout the annual cycle, migration patterns, and determining if there were distinct populations, within species, across North America. These studies relied largely upon satellite telemetry information to identify winter, breeding, and molting areas of sea ducks. New information from band recovery and genetic markers was added, contributing to hypotheses and initial conclusions about population delineation. Information on population units across North America is critical for identifying appropriate scales for evaluating population status and trends through annual monitoring surveys, harvest assessments, habitat protection and measuring effectiveness of management applications. Previous descriptions of population segments were for single species or smaller groups of similar species. Here, we summarize current knowledge on the general distribution and population segments of 13 species of sea ducks in North America by comparing range maps to long-term

${ }^{1}$ U.S. Geological Survey, Alaska Science Center

${ }^{2}$ New York State Department of Environmental Conservation

${ }^{3}$ U.S. Fish and Wildlife Service, Migratory Bird Management, Alaska

${ }^{4}$ Environment and Climate Change Canada, Science and Technology, British Columbia

${ }^{5}$ Environment and Climate Change Canada, Science and Technology, Ontario

${ }^{6}$ Environment and Climate Change Canada, Canadian Wildlife Service, New Brunswick

${ }^{7}$ Environment and Climate Change Canada, Canadian Wildlife Service, Québec

${ }^{8}$ U.S. Fish and Wildlife Service, Migratory Bird Management, Massachusetts

${ }^{9}$ U.S. Geological Survey, Patuxent Wildlife Research Center

${ }^{10}$ Duck Unlimited Canada

${ }^{11}$ Rhode Island Department of Environmental Management

${ }^{12}$ Environment and Climate Change Canada, Canadian Wildlife Service, Northwest Territories

13 U.S. Fish and Wildlife Service, Migratory Bird Management, Maryland

${ }^{14}$ Washington Department of Fish and Wildlife
\end{abstract}


band recovery, genetic, and satellite telemetry data to inform population delineation assessments and future research. These comparisons show a high degree of consistency in population patterns for most species across the independent data types. These maps provide a foundation for developing new hypothesis-driven research to address remaining knowledge gaps and questions about population differentiation, annual cycle distribution, habitat use, and harvest assessment.

\section{Introduction}

Sea ducks are a group of waterfowl comprising 21 species worldwide. They typically breed in mid- to northern-latitude areas of the globe, and nearly all rely upon marine habitats for much of their annual cycle. In North America, most sea duck species remained poorly studied up until the mid-twentieth century (Derksen and others, 2015). This lack of information was largely due to the remote breeding and wintering locations of many sea duck species and a greater emphasis placed on the biology and management of geese and dabbling ducks that are of greater hunting interest. In the mid-1990s, significant interest in sea duck biology and population trends began an era of research on this group of species (Derksen and others, 2015), much of which was funded by the Sea Duck Joint Venture (Batt, 2016), a program of the North American Waterfowl Management Plan. Among several priorities for research was a need to understand if and where definable population segments existed across North America because, for many species, little was known about migratory routes, significant breeding and wintering areas, and how these areas should be partitioned into biologically meaningful populations for monitoring and management. Concurrently, there was significant advancement in satellite telemetry and genetic methods that allowed for enhanced assessment of sea duck migration patterns and population differences among breeding and wintering areas. Additionally, despite most sea ducks being banded and harvested at low numbers (Rothe and others, 2015), band recovery data for many sea duck species are useful for a variety of important topics, such as migratory patterns that inform population differentiation (Pearce and others, 2005, 2014; Thomas and others, 2008), population models for harvest assessments (Gilliland and others, 2009) and extent and origins of disease outbreaks (Iverson and others, 2016).

Here, our objectives were to (1) provide a graphical depiction of geographic distribution of 13 species and their migratory patterns based on existing genetic, band recovery, and telemetry data sets, (2) highlight where gaps remain or where no additional information from a certain marker type is needed, (3) infer broad patterns of population delineation across North America, and (4) offer a starting point for future hypothesis-driven research to fill remaining information gaps (Esler and others, 2015). This graphical approach also provides a baseline for more quantitative assessments (for example, Lamb and others, 2019). Throughout this report, the term 'population delineation' refers to a process whereby significant information is available to conclude that ecologically or evolutionarily segregated populations exist such that separate management plans could be developed for each population. This process is not formalized (see Rushing and others, 2016), and thus the ability to delineate populations may vary by the level of information available for each species and region. 


\section{Methods}

We compiled information on North American sea ducks to help guide research and monitoring goals of the Sea Duck Joint Venture. Thus, this report includes information on the 13 species that the Sea Duck Joint Venture focuses on in its planning and research support: king eider (Somateria spectabilis), common eider (S. mollissima), harlequin duck (Histrionicus histrionicus), surf scoter (Melanitta perspicillata), white-winged scoter (M. deglandi), black scoter (M. americana), long-tailed duck (Clangula hyemalis), bufflehead (Bucephala albeola), common goldeneye (B. clangula), Barrow's goldeneye ( $B$. islandica), hooded merganser (Lophodytes cucullatus), common merganser (Mergus merganser), and red-breasted merganser (M. serrator). We developed four maps for each species: geographic range; mitochondrial (mt) DNA and genome information; band recovery data; and polygons of satellite telemetry locations. Additionally, we note information on known behaviors and other population specific markers, such as stable isotopes and morphological data that may inform a determination of discreet population segments.

Geographic range maps were initially based on information in Rodewald (2015) and then updated by the Sea Duck Joint Venture Continental Technical Team. However, since range maps are being continually updated, they are used here for general reference to compare to genetic, band recovery and telemetry data. For genetic information, mtDNA haplotypic frequencies at sampled locales for each species were provided by published literature (see section, "Species Maps"). Each haplotype is represented by a unique color in pie charts shown in "Species Maps." Size of pie charts is identical across all species maps and is not based on frequency of occurrence. Haplotypes represented by a single individual were not included because of the large number of these singleton haplotypes in some species. For scoter species, pie charts depict the proportion of individuals probabilistically assigned to a genetic cluster based on reduced representation genome sequence data (ddRAD; Sonsthagen and others, 2019).

For band recovery data, we queried the U.S. Geological Survey (USGS) Bird Banding Laboratory (2018) for all sea duck information. We obtained all band recovery data from 1922 to 2018 and then excluded all recoveries that were not from hunter-harvest events. We did not summarize the total number of birds banded, only the number of recovered bands and their banding and recovery location by species. We removed molting birds from our data set (see details below) so that the maps would reflect only breeding, wintering, and migratory areas between breeding and wintering sites. Many adults segregate by sex during the molting period and males (and some females) undertake long-distance molt migrations to areas that are often outside breeding ranges. There is also limited evidence that dispersal occurs among populations during the molt period (Pearce and others, 2009a) and our goal was to demonstrate any overlap of breeding and wintering areas that might contribute to dispersal between populations at a broad scale, such as between Alaska and lower latitude regions of western and eastern North America.

To remove molting birds from our analyses, we excluded all data records of adult birds (after-hatch year, second year, after-second year, third year, and after-third year) banded during the flightless remigial molt period, defined in our dataset as July 1 through September 30. Sea ducks are known to remain at molting sites well after regaining flight capability (O'Connor, 2008; Robert and others 2008), but banding activities are typically restricted to the flightless period. We retained local and hatch year birds banded during the timeframe of molting because we assumed they hatched locally and thus reflect a known breeding area. We also excluded all adult birds of unknown sex during the molt period, which may have removed females who do 
molt on or near their breeding areas. Colors used to depict band and recovery locations are for illustrative purposes only and do not represent defined populations.

For satellite telemetry data, nearly all ARGOS location information from published studies is not publicly available. Therefore, we did not map actual data from these studies. Instead, we digitized generalized polygons of telemetry locations from maps depicted in published sources (see section, "Species Maps"). Similar to band recovery data, we excluded molting locations and migration tracks to and from molting areas determined by telemetry data because they are not known to be important factors in gene flow and thus, population delineation. We summarized the total number of transmitters deployed by species but because not all transmitters provided location data the original studies should be consulted for final sample sizes used in analyses. Polygon colors used in figures (see section, "Species Maps") are for illustrative purposes only and do not represent defined populations.

\section{Species Maps}

\section{King Eider (Somateria spectabilis)}

\section{Geographic distribution}

The king eider in North America breeds primarily in high and sub-arctic Canada and northern Alaska (fig. 1A; Powell and Suydam, 2012). During winter, the king eider is dispersed throughout the Bering Sea, southwest Alaska and parts of southcentral Alaska. Along the east coast of North America, the species is observed at sea and along coastal portions of Labrador, Québec, Newfoundland and Nova Scotia, and parts of the northeastern U.S. (Powell and Suydam, 2012).

\section{Genetic}

Pearce and others (2004) examined nuclear biparentally-inherited microsatellite loci and mtDNA sequence data from the cytochrome $b$ gene and determined no evidence of population genetic structure in this species. These authors concluded that both evolutionary and more contemporary population growth (via genetic analyses) and high levels of gene flow likely homogenized gene frequencies among both nesting and wintering areas over time, leading to the finding of no population genetic differentiation among breeding and wintering areas in North America.

\section{Band recovery}

Our band recovery dataset contained 41 records (fig. $1 C$ ), of which most were banded near Karrak Lake in the Queen Maud Gulf area of Canada. Mehl and others (2004) noted that king eiders banded there were subsequently recovered in both Pacific and Atlantic Ocean wintering areas. Birds from Karrak Lake also were recovered in Russia and Alaska. Birds banded in Alaska were recovered farther west, similar to satellite telemetry markers deployed in those same locations (Phillips and others, 2006). 


\section{Telemetry}

A total of 125 transmitters have been deployed in king eiders: 36 by Mosbech and others (2006a), 60 by Phillips and others (2006), and 29 by Dickson (2012a). These telemetry studies determined that king eiders marked in two locations in northern Alaska (Phillips and others, 2006) and a location in Arctic Canada (Dickson, 2012a) during the breeding season, remained within the western Arctic region during the rest of the annual cycle (fig. 1D). Males marked in Canada either returned to arctic Canada or migrated to Russia in subsequent breeding seasons. Winter distribution of birds marked with transmitters in Alaska and Canada included areas of the Kamchatka Peninsula, Russia, and coastal mainland Alaska. Petersen and Savard (2015; fig. 8.1) present an overall map of spring migration routes for western Arctic king eiders based on single best locations from satellite telemetry studies. King eiders marked in western Greenland and northern Hudson Bay (East Bay; Mosbech and others, 2006a) remained in the northern Atlantic Ocean region post-breeding.

\section{Summary}

The hypothesis of population delineation between western and eastern Arctic populations (those wintering in either the Pacific or Atlantic Ocean regions; see Powell and Suydam, 2012) was not supported by genetic or band recovery data (Pearce and others, 2004). Generally, king eiders breeding in the eastern and western portions of North America winter in the closest respective ocean; however, band recovery, satellite telemetry, and stable isotope information (Mehl and others, 2004) suggest that the Queen Maud Gulf region of Canada is a sympatric breeding area used by king eiders that winter in both Pacific and Atlantic Ocean regions. More contemporary genetic analyses may help to further refine areas of sympatry and allopatry to better understand levels of gene flow among Pacific and Atlantic populations of king eiders. 


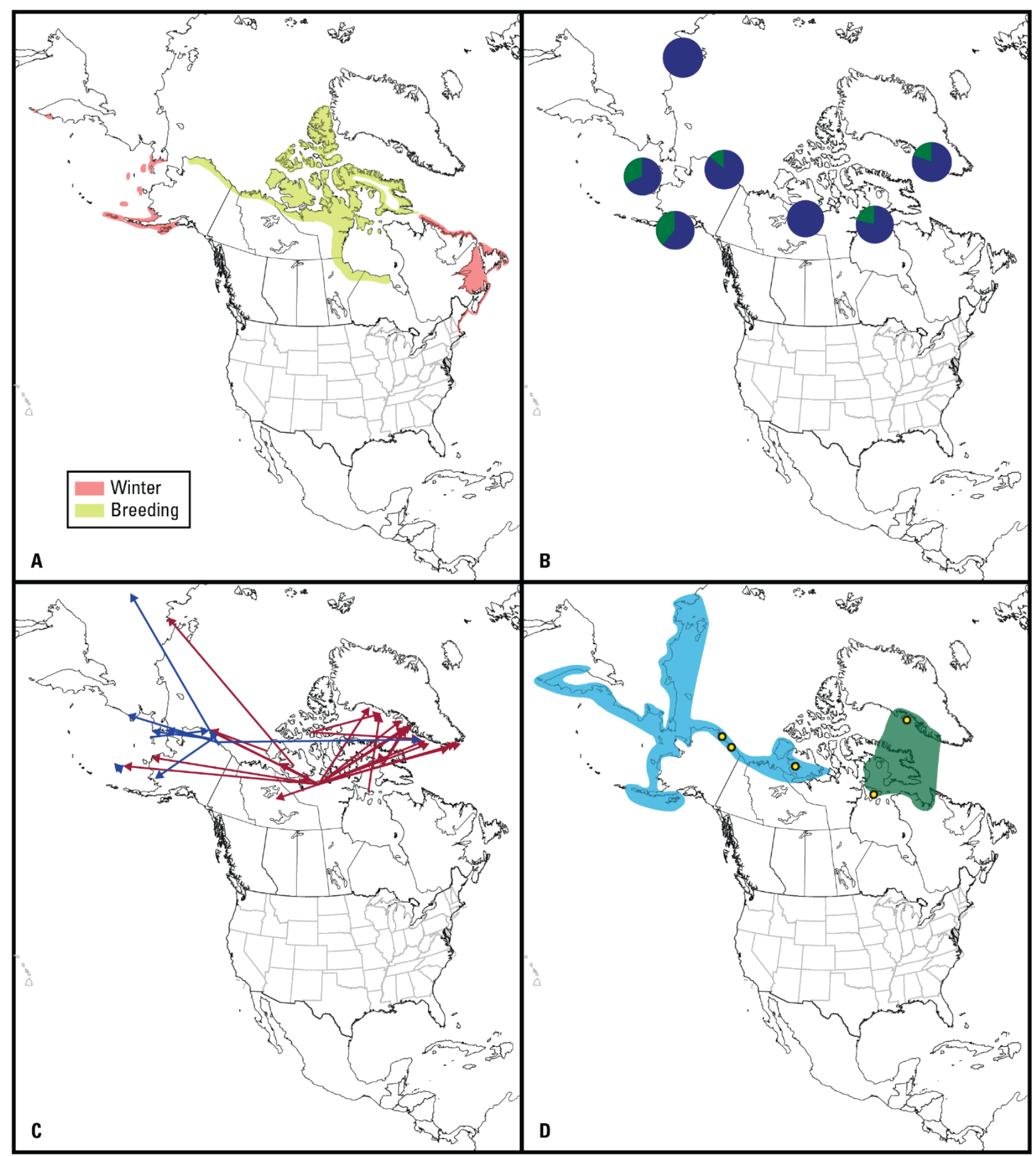

Figure 1. Maps showing king eider (Somateria spectabilis) information from $(A)$ geographic distribution, $(B)$ genetic, $(C)$ band recovery, and $(D)$ telemetry studies across North America and Greenland. Yellow dots in $D$ show telemetry marking locales. Molting locations are not shown. Colors used in panels $A-D$ are for illustrative purposes only (see section, "Methods"). 


\title{
Common Eider (S. mollissima)-Pacific Subspecies
}

\author{
Geographic Distribution
}

The Pacific subspecies of the common eider (S. m. v-nigra) in North America breeds in coastal areas of Alaska and high arctic Canada to Queen Maud Gulf (fig. 2A; Goudie and others, 2000). The subspecies winters in coastal areas of the Bering Sea, Aleutian Islands, and Kodiak Island of Alaska.

\section{Genetic}

Sonsthagen and others (2011) determined that Pacific common eiders sampled within their range in Alaska and Canada were genetically differentiated from other common eider subspecies based on both nuclear and mtDNA. Additionally, within the Pacific region, Sonsthagen and others $(2007,2009,2010,2011,2013)$ and Petersen and others (2015) observed evidence for fine-scale spatial genetic structuring for both mtDNA and nuclear markers among breeding locations.

\section{Band Recovery}

Our band recovery dataset included 11 records (fig. 2C). Eiders marked in northern Alaska and Canada were recovered within the range of the Pacific subspecies in coastal areas of northern Russia and Alaska.

\section{Telemetry}

A total of 200 transmitters have been deployed on Pacific common eiders in Alaska and Canada: 41 by Petersen and Flint (2002), 89 by Petersen and others (2015), and 70 by Dickson (2012b). These studies determined that marked birds remained in the Pacific Ocean basin postbreeding and did not overlap with other subspecies of common eiders and, in agreement with genetic information, finer-scale population segregation exists within the range of the Pacific subspecies. For example, Petersen and Flint (2002) determined that breeding populations could be delineated based on the movement of females marked on the Yukon-Kuskokwim Delta and the North Slope of Alaska and their use of largely different wintering areas in the Bering Sea. Additionally, Petersen and others (2015) determined that female common eiders marked in the Aleutian Islands remained there year-round. However, movements of adult male common eiders demonstrated dispersal within the range of the Pacific subspecies as some male eiders marked in Canada returned either to arctic Canada or to Russia in subsequent breeding seasons (Dickson 2012b).

\section{Summary}

There is limited band recovery information for Pacific common eiders, but genetic and telemetry information suggest significant differentiation from other common eider subspecies within North America. Telemetry and genetic studies demonstrated that fine scale population structure occurs within the range of the Pacific subspecies for the three primary breeding populations examined (Aleutian Islands, Yukon-Kuskokwim Delta, and the North Slope of Alaska). If needed, additional resolution of population connectivity within the Pacific subspecies could be obtained with a combination of genetic and telemetry methods. 


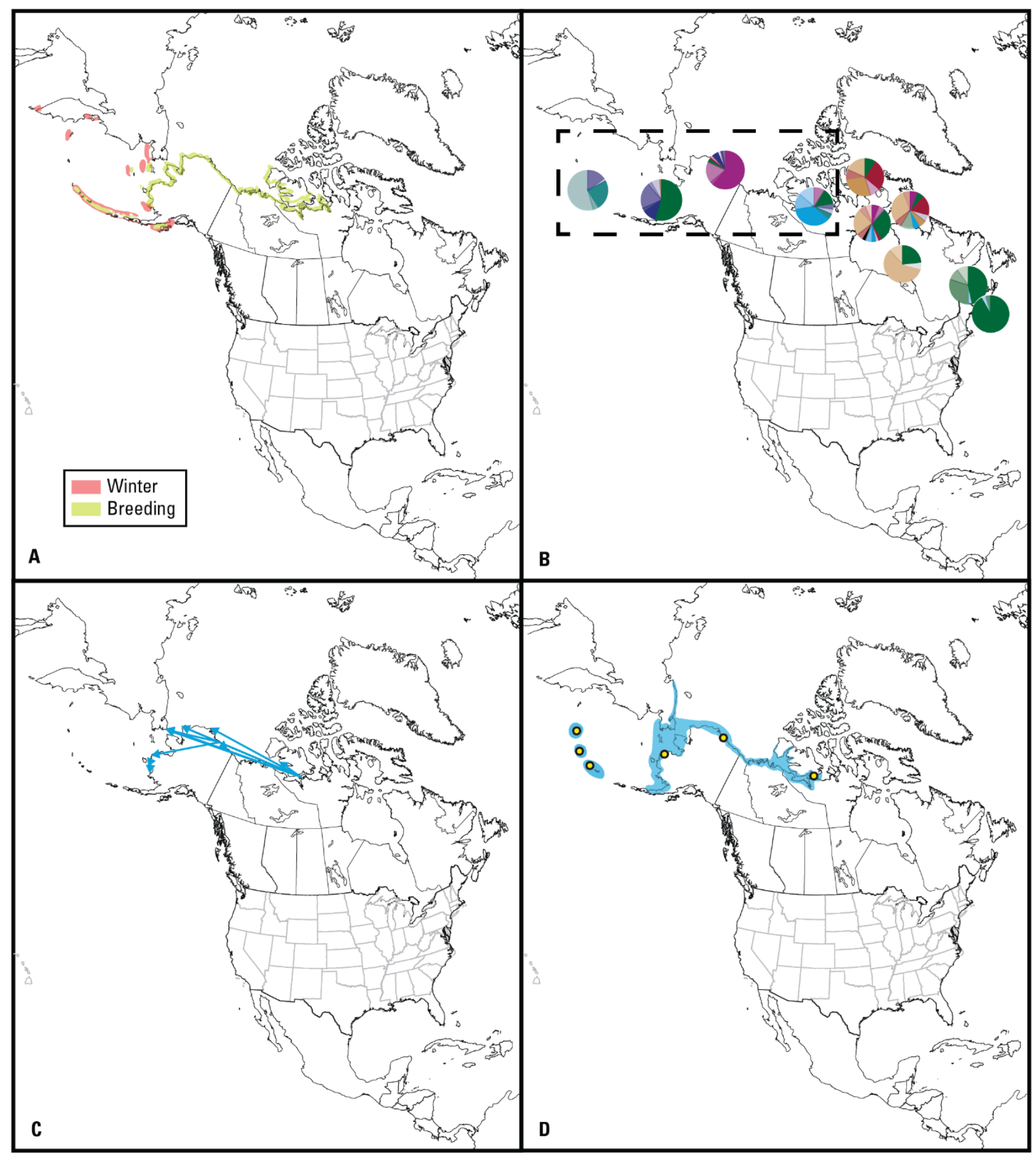

Figure 2. Map showing common eider (S. mollissima; Pacific subspecies) information from $(A)$ geographic distribution, $(B)$ genetic, $(C)$ band recovery, and $(D)$ telemetry studies across North America. Dashed box in $B$ shows data from Pacific common eider sampling locales. Yellow dots in $D$ show telemetry marking locales. Molting locations are not shown. Colors used in panels $A-D$ are for illustrative purposes only (see section, "Methods"). 


\section{Common Eider (S. mollissima)-Hudson Bay Subspecies}

\section{Geographic Distribution}

The Hudson Bay subspecies of common eider (S. m. sedentaria) has a restricted annual distribution within Hudson and James bays, Canada (fig. 3A; Abraham and Finney, 1986; Goudie and others, 2000; Sonsthagen and others, 2011).

\section{Genetics}

As mentioned above, Sonsthagen and others (2011) determined that the three subspecies of common eiders in Canada are not completely resolved genetically, likely from the historical colonization of the same glacial refugia, insufficient time for genetic differentiation to occur and (or) contemporary gene flow among populations. Using nuclear and mtDNA, few genetic differences were observed across breeding locations of Hudson Bay, including those from areas within the range of the Hudson Bay subspecies (Belcher Islands) and areas farther north (Baffin Island, Southampton Island, Hudson Strait, and Mansel Island) in the range of the northern subspecies.

\section{Band recovery}

Our band recovery data set contained only a single record (fig. 3C) from a bird banded in western Hudson Bay near La Perouse Bay and recovered in southern Manitoba.

\section{Telemetry}

No Hudson Bay common eiders have been marked.

\section{Summary}

Morphology and range information are the primary data determining the identification of the Hudson Bay common eider from other subspecies in North America (Goudie and Robertson, 2000). However, genetic information collected by Sonsthagen and others (2011) is less definitive regarding the delineation of the Hudson Bay common eider from other subspecies, but more detailed genomic analyses may provide greater resolution among common eider subspecies that breed in the Hudson Bay region. 


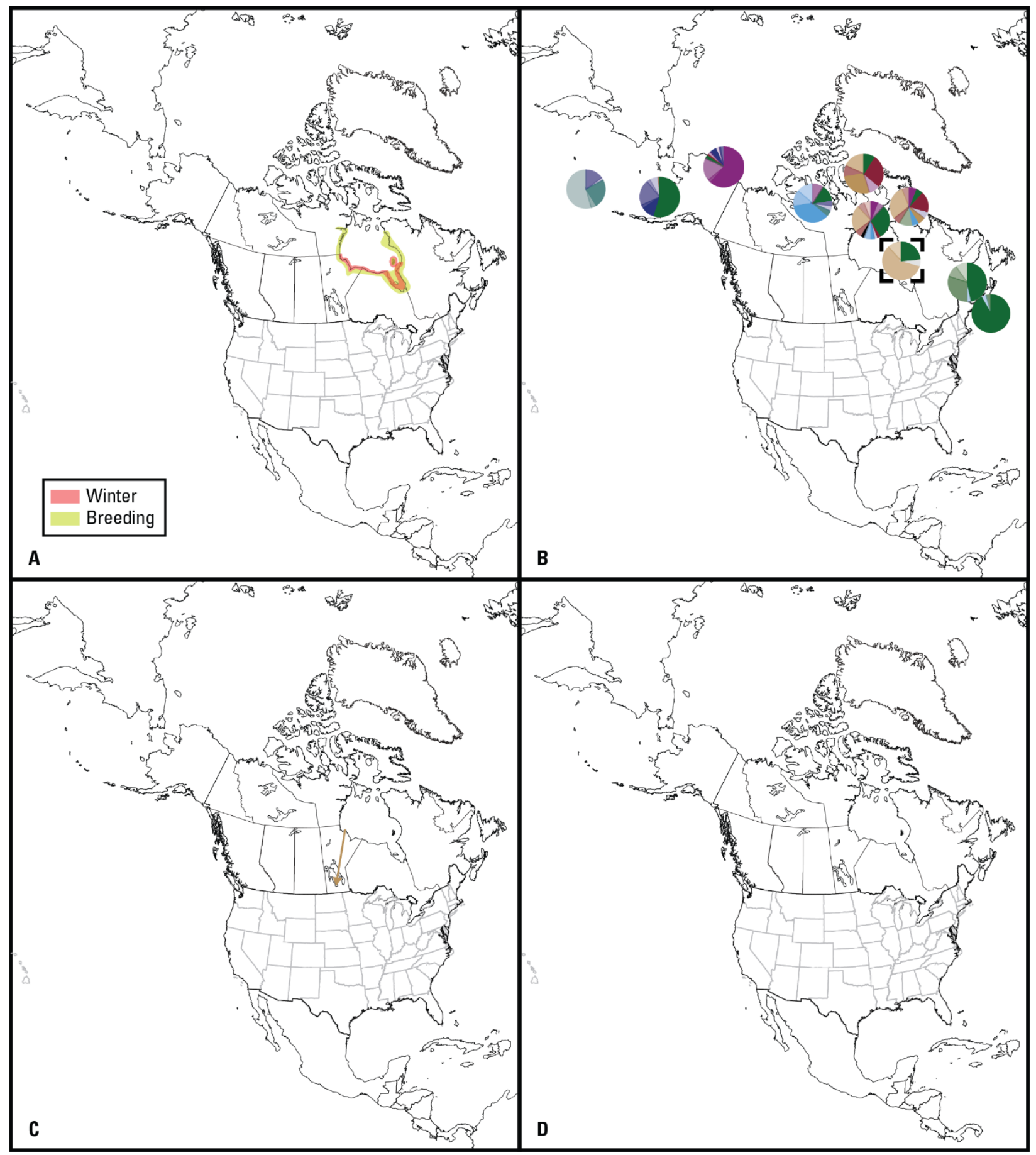

Figure 3. Maps showing common eider (S. mollissima; Hudson Bay subspecies) information from $(A)$ geographic distribution, $(B)$ genetic, $(C)$ band recovery, and $(D)$ telemetry studies across North America. Dashed box in $B$ shows data from Hudson Bay common eider sampling locales. Molting locations are not shown. Colors used in panels $A-C$ are for illustrative purposes only (see section, "Methods"). 


\section{Common Eider (S. mollissima)-Northern Subspecies}

Geographic Distribution

The northern subspecies of the common eider ( $S$. m. borealis) breeds throughout the eastern portion of the Canadian Arctic Archipelago and south along the Atlantic coast of Canada to Labrador (fig. 4A; Goudie others, 2000). During winter, birds occur in western Greenland and along the Québec North Shore coast and the Newfoundland-and-Labrador coast, Canada (Goudie and others, 2000).

\section{Genetic}

As mentioned earlier, Sonsthagen and others (2011) determined that the three subspecies of common eiders in Canada are not differentiated genetically. Using nuclear and mtDNA, few genetic differences were observed across breeding locations of Hudson Bay, including those from areas within the range of the northern subspecies (Baffin Island, Southampton Island, Hudson Strait, and Mansel Island) and Hudson Bay subspecies.

\section{Band Recovery}

The band recovery dataset contained 340 records (fig. 4C). The distribution of band recoveries for the northern subspecies is largely from birds banded in East Bay on Southampton Island, Canada (Descamps and others, 2009) with recoveries in western Greenland and the Atlantic coast of eastern Canada. Overlap with the American subspecies (S. $m$. dresseri) occurs during winter in eastern Canada and the northeastern U.S.

\section{Telemetry}

A total of 41 transmitters have been deployed in northern common eiders: 26 by Mosbech and others (2006b) and 15 by Savard and others (2011). Mosbech and others (2006b) determined that northern common eiders undertake an east-west migration pathway that links Arctic Canada (Hudson Bay) to not only maritime wintering areas near Québec and Newfoundland-andLabrador, but also wintering areas in southwestern Greenland. Similarly, Savard and others (2011) determined eiders marked in Ungava Bay, Canada, also undertook this east-west flyway with some birds migrating south to maritime eastern Canada and other birds flying east to southwestern Greenland (fig. 4C). Additionally, Mosbech and others (2006b) observed that eiders marked in southwestern Greenland ranged from largely sedentary birds that nested within 45 kilometers $(\mathrm{km})$ of their wintering area to eiders that migrated more than 2,000 km between breeding and wintering areas.

\section{Summary}

The presence of population structure within northern common eiders has permitted the use of banding and telemetry data to inform population models for harvest assessments (Gilliland and others, 2009) and origins and transmission of disease outbreaks (Iverson and others, 2016). Savard and others (2011) noted that use of different wintering areas by birds marked in Ungava Bay may be a common pattern for most breeding eiders within the northern Hudson Bay region. Additionally, Mosbech and others (2006b) noted some segregation of wintering common eiders in Greenland that reflects Greenland versus Canadian breeding area origins. Thus, northern 
common eiders that breed in western Greenland winter farther north than do those that breed on Southampton Island. This hypothesis is supported by band recoveries of northern common eiders marked in Upernavik, Greenland, from 1933 to 1972 and on Southampton Island in the 1990s (Mosbech and others, 2006b). Furthermore, this winter segregation in western Greenland corresponded to differences in structural size of tracked birds; females from Southampton Island were structurally smaller than those marked in Greenland (Mosbech and others, 2006b). More detailed genomic analyses may provide greater resolution for testing differences among common eider subspecies that breed in the Hudson Bay region. 


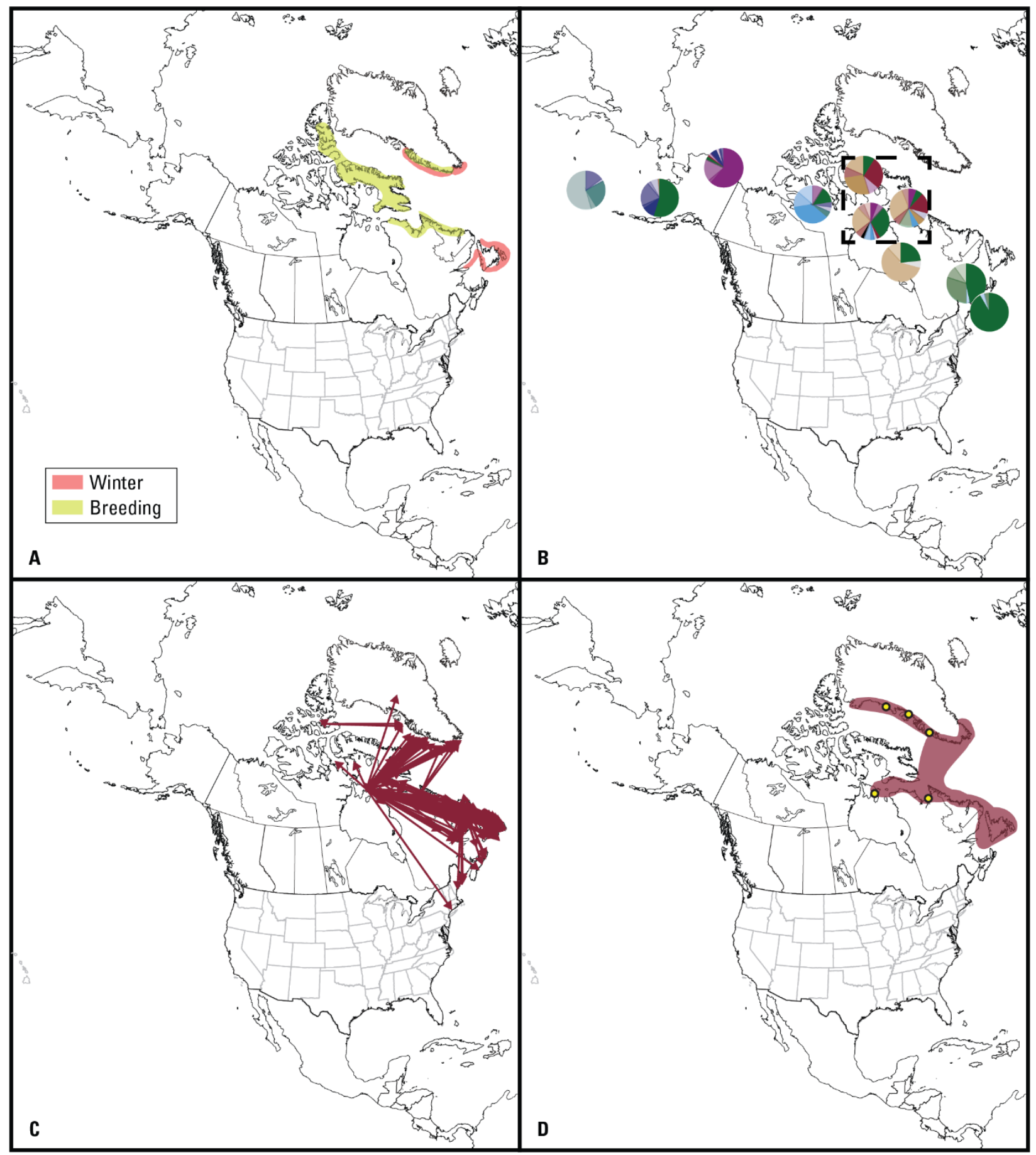

Figure 4. Maps showing common eider (S. mollissima; northern subspecies) information from $(A)$ geographic distribution, $(B)$ genetic, $(C)$ band recovery and $(D)$ telemetry studies across North America. Dashed box in $B$ shows data from northern common eider sampling locales. Yellow dots in $D$ show telemetry marking locales. Molting locations are not shown. Colors used in panels $A-D$ are for illustrative purposes only (see section "Methods"). 


\section{Common Eider (S. mollissima)-American Subspecies}

Geographic Distribution

The American subspecies of the common eider (S. m. dresseri) (fig. $5 \mathrm{~A}$; Goudie and others, 2000) breeds and winters along the maritime coast of eastern Canada and the northeastern coastline of the U.S. Breeding areas are primarily along the St. Lawrence Estuary and Gulf of Québec and the coasts of the Atlantic Provinces, Canada, with wintering areas in the southern part of the range but also along the coast southward to Delaware Bay (Goudie and others, 2000).

Genetic

Sonsthagen and others (2011) determined that American common eider breeding samples from New Brunswick and Nova Scotia clustered genetically with those of Hudson common eiders sampled on the Belcher Islands, Hudson Bay.

\section{Band Recovery}

Our band recovery dataset contained 3,219 records (fig. 5C). Birds banded within the geographic range of the American common eider were recovered largely within the known geographic range of the subspecies. However, several recoveries were recorded to the west and south of northeastern U.S. and of eastern Canada.

\section{Telemetry}

Beuth and others (2017) deployed 24 transmitters and determined that wintering American common eiders marked in Rhode Island (fig. 5D), migrated northward to breeding areas within their suspected geographic range that includes Maine, the St. Lawrence Estuary, Gulf of St. Lawrence, and Nova Scotia, Canada.

\section{Summary}

Although genetic data are not definitive, banding data indicate that American common eiders are distinct from other eider subspecies. Banding and telemetry data for the American common eider that delineated breeding, wintering, and migratory areas have been used to develop population models for harvest assessments (Gilliland and others, 2009) and to examine extent, origins and transmission of disease outbreaks (Iverson and others, 2016). In response to recent population declines of American common eiders and questions about sustainable harvest levels (Gilliland and others, 2009), finer-scale population genetic assessments are underway to identify the breeding ground origins of American common eiders harvested in winter. 




Figure 5. Maps showing common eider (S. mollissima; American subspecies) information from $(A)$ geographic distribution, $(B)$ genetic, $(C)$ band recovery, and $(D)$ telemetry studies across North America. Dashed box in $B$ shows data from American common eider sampling locales. Yellow dots in $D$ show telemetry marking locales. Molting locations are not shown. Colors used in panels $A-D$ are for illustrative purposes only (see section, "Methods"). 


\section{Harlequin Duck (Histrionicus histrionicus)}

\section{Geographic Distribution}

The harlequin duck in North America has a disjunct breeding distribution (fig. $6 \mathrm{~A}$; Robertson and Goudie, 1999). In western North America, wintering aggregations are observed primarily along coastlines of Alaska (Aleutian Islands, southwestern, southcentral and southeast), British Columbia, Washington, and Oregon. In eastern North America, wintering areas included Greenland, some locations on the south coast Newfoundland, on the Gaspé Peninsula south coast in Québec, and along the Atlantic coast from Nova Scotia south to Maryland (Robertson and Goudie, 1999).

\section{Genetic}

Robertson and Goudie (1999) reported evidence of genetic differences among eastern breeding populations, but little evidence for differences among breeding populations in western North America. Lanctot and others (1999) found limited evidence for genetic structure among wintering areas across areas of Prince William Sound and Kodiak Island, Alaska.

\section{Band Recovery}

Our dataset included 87 band recoveries, with only one hunter shot bird from the Atlantic coast, and was thus uninformative regarding population delineation (fig. $6 \mathrm{C}$ ). Thomas and others (2008) determined that band recovery data from eastern North America were consistent with past telemetry studies (Brodeur and others, 2002) regarding population affiliations. Additionally, these authors concluded that complete geographic separation of the eastern North American and Greenland wintering populations could not be determined from the band recovery data. Iverson and others (2004) used band recovery data from Prince William Sound, Alaska, and concluded that wintering aggregations of harlequin ducks may be demographically independent at a much finer scale than was observed with genetic markers by Lanctot and others (1999). However, it is uncertain if high levels of winter site fidelity are a measure of demographic independence and population delineation (see Esler and others, 2006; Pearce and Talbot, 2006).

\section{Telemetry}

A total of 44 transmitters have been deployed on harlequin ducks in the northeastern Atlantic area of North America: 25 by Brodeur and others (2002), 11 by Chubbs and others (2008), and 8 by Robert and others (2008). These studies determined that harlequin ducks breeding in Labrador, Newfoundland, New Brunswick and northern Québec winter in the Atlantic coastal region of the U.S. (Maine) and in southwestern Greenland (fig. 6D). Additionally, Brodeur and others (2002) found evidence for distinct migration patterns in the two eastern Nearctic populations (Hudson Bay and Gaspé Peninsula, Canada) marked with transmitters (not shown in fig. $6 D$ ), suggesting distinct populations that was also supported by preliminary genetic and morphological evidence. Robert and others (2008) concluded that it remains unclear if there is any breeding overlap of harlequin ducks that winter in Greenland and the eastern North America, whereas Chubbs and others (2008) concluded that there is probably overlap in central Labrador. 


\section{Summary}

The geographic isolation of western and eastern ranges of the harlequin duck suggests that these are likely discrete population segments. Robertson and Goudie (1999) and Brodeur and others (2002) discuss preliminary genetic and morphological analyses that indicate differences within and among harlequin duck populations in eastern and western North America, but details are not available. Additionally, Thomas and others (2008) suggest that two populations could be recognized for harlequin ducks in eastern North America: one that breeds in southern Labrador, parts of the Labrador coast, the Gaspé Peninsula in Québec, and interior Newfoundland and a second that winters in Greenland and breeds in northern Nunavut, northern Québec, and northern/central Labrador. Completing range-wide genetic comparisons, making other genetic, telemetry and morphological data publicly available and initiating a more contemporary population genetic analysis of breeding birds throughout the North American distribution of harlequin ducks would provide appropriate data to test hypotheses about population differentiation across the range of this species. 




Figure 6. Maps showing harlequin duck (Histrionicus histrionicus) information from $(A)$ geographic distribution, $(B)$ genetic, $(C)$ band recovery, and $(D)$ telemetry studies across North America. Yellow dots in $D$ show telemetry marking locales. Molting locations are not shown. Colors used in panels $A-D$ are for illustrative purposes only (see section, "Methods"). 


\section{Surf Scoter (Melanitta perspicillata)}

Geographic Distribution

The surf scoter in North America breeds across the high latitude boreal forest regions of Alaska and Canada and winters broadly along coastal areas of the Pacific and Atlantic Ocean (fig. 7A; Anderson and others, 2015).

Genetic

Sonsthagen and others (2019) used double-digest restriction-associated DNA sequence (ddRAD) and microsatellite genotype data and uncovered no evidence for genetic structure within North America, suggestive of high gene flow and connectivity among breeding and wintering regions (fig. $7 B$ ).

\section{Band Recovery}

Our data set included 98 band recoveries for surf scoters and showed no overlap in the distribution of recoveries for birds banded in the western and eastern regions of North America (fig. 7C).

Telemetry

A total of 323 transmitters have been deployed in surf scoters in North America: 85 by De La Cruz and others (2009), 36 by Rosenberg and others (2019a), and 202 by the Sea Duck Joint Venture (2015) and Lamb and others (2019). Based on the general map of these data, there is a region of breeding sympatry in northern Canada by surf scoters marked in western and eastern North America (fig. 7D).

In western North America, De La Cruz and others (2009) marked surf scoters in four different wintering areas along the Pacific Coast (fig. 7D); from San Quintin Bay, Baja California, Mexico, in the south to the Strait of Georgia, British Columbia, Canada, in the north. The authors restricted their dataset to range from the winter marking date to a breeding area settling or nest initiation date. The authors determined that surf scoters settled in breeding areas throughout central and northwest Canada and to a lesser extent, interior Alaska, that surf scoters did not follow specific routes to breeding areas based on wintering site and that there was overlap in breeding distribution among birds marked in the four different wintering areas. Rosenberg and others (2019a) deployed transmitters in Prince William Sound, Alaska. Similar to De La Cruz and others (2009), the authors determined that breeding locations were likely in interior Alaska and northwestern Canada. Subsequent wintering locations, determined for seven birds, included the coastal Alaska Peninsula, Sitka Sound, and Prince William Sound and water surrounding Vancouver Island, British Columbia.

In eastern North America, the Sea Duck Joint Venture (2015) and Lamb and others (2019) deployed transmitters at five locations (fig. 7D). Breeding areas covered northeastern Canada, northern Ontario and Manitoba, and the southeast part of the Northwest Territories. Wintering areas are along the Atlantic coast of North America. 
For surf scoters, we observed some similar patterns for genetic and telemetry data across North America, but not for band recovery data. Telemetry information identifies a minimum area of summer (breeding) sympatry of Pacific and Atlantic wintering birds in northern Canada, west of Hudson Bay, that may contribute to gene flow between these two populations (Sonsthagen and others, 2019). Additional surf scoters have been marked in western North America, but data are not yet publicly available. These telemetry data on wintering areas could potentially refine the size of the sympatric region. 




Figure 7. Maps showing surf scoter (Melanitta perspicillata) information from $(A)$ geographic distribution, $(B)$ genetic, $(C)$ band recovery, and $(D)$ telemetry studies across North America. Yellow dots in $D$ show telemetry marking locales. Molting locations are not shown. Colors used in panels $A-D$ are for illustrative purposes only (see section, "Methods"). 


\section{White-Winged Scoter (Melanitta deglandi)}

\section{Geographic Distribution}

The white-winged scoter in North America breeds across high latitudes, essentially from eastern Manitoba northwest into northern Alaska (fig. 8A; Brown and Fredrickson, 2019; Amundson and others, 2019). The species winters in temperate regions along the Great Lakes, and mid-latitude coastal regions of the U.S. and Canada.

\section{Genetic}

Sonsthagen and others (2019) used double-digest restriction-associated DNA sequence (ddRAD) and microsatellite genotype data and concluded no or weak genetic structure within North America, suggestive of high gene flow and connectivity among breeding and wintering regions (fig. $8 B$ ).

\section{Band Recovery}

The banding data we summarized included 68 band recoveries (fig. $8 C$ ) and these recoveries were similar to patterns from telemetry data (fig. $8 D$ ). White-winged scoters banded on Redberry Lake, Saskatchewan (Houston and Brown, 1983; Swoboda, 2007), were recovered on both Pacific and Atlantic wintering areas. Recoveries of birds banded farther north in Canada were subsequently recovered along the Atlantic coast, but also in Alaska. Nearly all whitewinged scoters banded in Alaska were recovered in or near Alaska.

\section{Telemetry}

A total of 73 transmitters have been deployed in white-winged scoters in North America: 22 by Rosenberg and others (2019b) and 51 by the Sea Duck Joint Venture (2015), Meattey and others (2018), and Lamb and others (2019). Similar to surf scoters, breeding distributions of some white-winged scoters marked in western and eastern North America overlap during summer in portions of northern and central Canada.

In western North America, Rosenberg and others (2019b) marked white-winged scoters in Prince William Sound, Alaska, and determined breeding areas are located in interior Alaska and the Yukon and Northwest territories of Canada. Fifteen of the 22 white-winged scoters provided wintering locations and most of these $(n=9)$ returned to Prince William Sound. Other wintering areas included the eastern Aleutian Islands, the Alaska Peninsula, and northern Gulf of Alaska. None of the 15 birds moved into southeast Alaska or Puget Sound (fig. 8D). In eastern North America, the Sea Duck Joint Venture (2015), Meattey and others (2018) and Lamb and others (2019) marked white-winged scoters in five locations (fig. 8D); most birds moved from the U.S. Atlantic coast where they wintered to northwestern breeding areas, but a few bred in northern Québec and Ontario. The few scoters that did not winter along the U.S. Atlantic coast stayed on the Great Lakes or in coastal Nova Scotia and eastern Newfoundland, Canada.

\section{Summary}

For white-winged scoters, we observed similar patterns for genetic, banding, and telemetry data across North America. From the banding and telemetry data, we determined that Alaska birds may be segregated from white-winged scoters wintering farther south. However, 
additional banding and telemetry in other areas is needed to confirm this population structure in western North America. Additional white-winged scoters have been marked in western North America, but data are not yet publicly available. By combining telemetry data polygons, we identified a minimum area in northern and central Canada, west of Hudson Bay, where whitewinged scoters that winter in western and eastern North America are sympatric in summer. Banding data shows that this region of sympatry may extend farther south in central Canada than is shown by the telemetry data. 


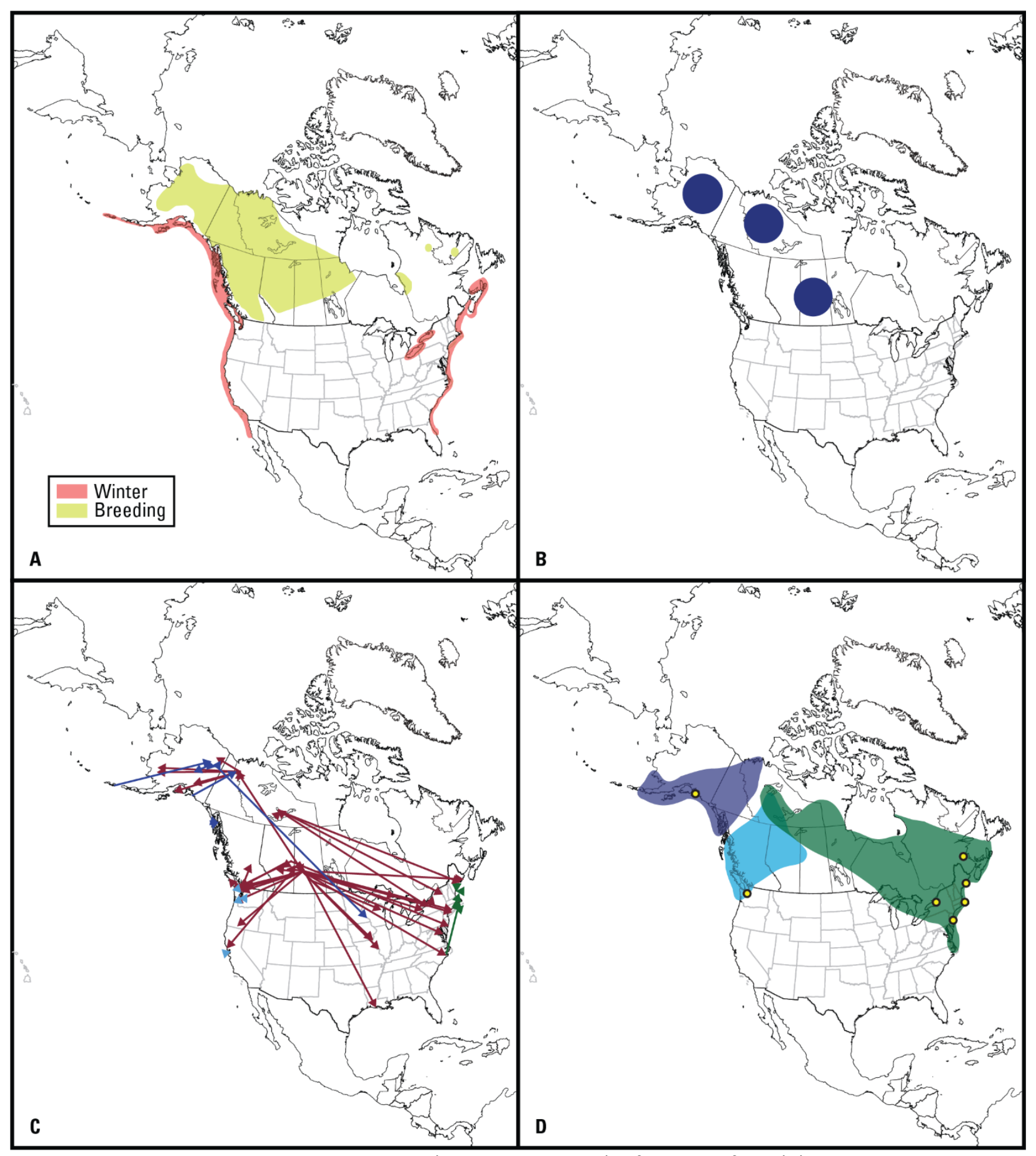

Figure 8. Map showing white-winged scoter (Melanitta deglandi) information from $(A)$ geographic distribution, $(B)$ genetic, $(C)$ band recovery, and $(D)$ telemetry studies across North America. Yellow dots in $D$ show telemetry marking locales. Molting locations are not shown. Colors used in panels $A-D$ are for illustrative purposes only (see section, "Methods"). 


\section{Black Scoter (Melanitta americana)}

Geographic Distribution

The black scoter in North America is characterized by a disjunct breeding distribution for birds that winter in western and eastern regions of the continent. Black scoters wintering in western North America breed primarily in Alaska (fig. 9A; Bordage and Savard, 2011), whereas the birds that winter in eastern North America breed in Labrador, northern Québec, and in an area that extends northwest from northern Ontario to eastern Northwest Territories (Sea Duck Joint Venture, 2015).

Genetic

Sonsthagen and others (2019) determined that in contrast to surf and white-winged scoters, black scoters have elevated levels of genetic divergence between sampling sites in Alaska and elsewhere in North America (fig. 9B). The authors concluded that these findings were concordant with the disjunct breeding distribution of the black scoter.

\section{Band Recovery}

Our band recovery data set consisted of 47 records (fig. 9C) and suggests no areas of sympatry between western and eastern distributions in North America.

\section{Telemetry}

A total of 108 black scoters have been marked for telemetry studies: all by the Sea Duck Joint Venture (2015) and Lamb and others (2019) in eastern North America at two locations (fig. $9 D$ ). Breeding locations were distributed in similar areas to surf and white-winged scoters; these telemetry data highlighted the importance of central Canada as a breeding area for Atlantic wintering black scoters, which was unsuspected a decade ago (Bordage and Savard, 2011).

\section{Summary}

Genetic and band recovery data reflect the disjunct breeding distribution of the black scoter. Black scoters have been marked in western North America, but data are not yet publicly available. Completion of these telemetry data may further demonstrate the disjunct distribution of western and eastern populations of black scoters. 


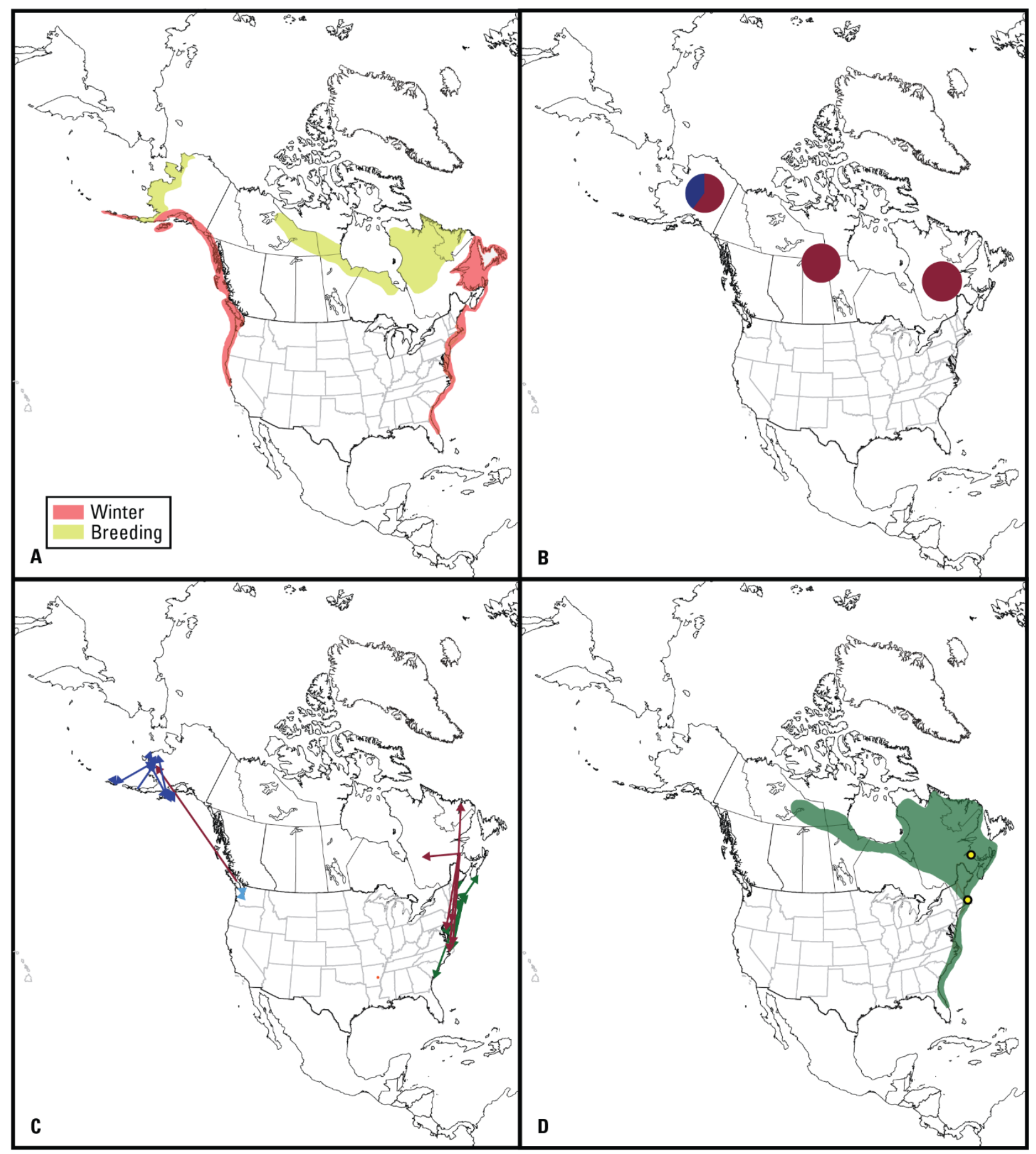

Figure 9. Maps showing black scoter (Melanitta americana) information from $(A)$ geographic distribution, $(B)$ genetic, $(C)$ band recovery, and $(D)$ telemetry studies across North America. Yellow dots in $D$ show telemetry marking locales. Molting locations are not shown. Colors used in panels $A-D$ are for illustrative purposes only (see section, "Methods"). 


\section{Long-Tailed Duck (Clangula hyemalis)}

\section{Geographic Distribution}

The long-tailed duck has a high-latitude breeding distribution and winters primarily along the sub-Arctic and temperate coastlines of North America and in the Great Lakes region (fig. $10 \mathrm{~A}$; Robertson and Savard 2002).

Genetic

Allison and others (2013) found no evidence for genetic differentiation among Pacific and Atlantic long-tailed duck populations based on museum specimen samples from Russia, Alaska, Nunavut, Massachusetts, and New York. Wilson and others (2015) observed significant differentiation among two groups or clades of mtDNA haplotypes. However, one clade was comprised of all sampling locations (eastern Russia, western and northern Alaska, and northern Canada), whereas the other clade was comprised almost exclusively of samples from western Alaska. Wilson and others (2015) concluded that these results reflect the isolation of two historical populations, with subsequent expansion by one clade to all sampling locations.

\section{Band Recovery}

Our band recovery data set consisted of 36 records (fig. 10C) and provided little information on population connectivity. Birds banded in northern Canada and along western Hudson Bay wintered in the Great Lakes and along the Atlantic coast. A single bird banded on Baffin Island, Canada, was recovered in Russia. Lawson (2006) examined 61 North America band recoveries from 1923 to 2004 and concluded hunter-killed long-tailed ducks from western and eastern coasts of North America and the Great Lakes region shared similar breeding areas.

\section{Telemetry}

A total of 127 long-tailed ducks have been marked: 14 by Petersen and others (2003), 9 by Mallory and others (2006), 56 by Bartzen and others (2017), and 48 by the Sea Duck Joint Venture (2015).

Petersen and others (2003) marked female long-tailed ducks on the Yukon-Kuskokwim Delta, Alaska, and determined that birds from this breeding area wintered in multiple locations throughout the north Pacific region (Petersen and others, 2003; fig. 10D). Bartzen and others (2017) marked male and female long-tailed ducks in western Arctic Canada during molt. Similar to long-tailed ducks marked in Alaska, birds marked by Bartzen and others (2017) wintered throughout the North Pacific region as far south as Haida Gwaii Archipelago, Canada. Some birds wintered in Japan and South Korea (not shown in fig. 10D).

The Sea Duck Joint Venture (2015) marked long-tailed ducks in multiple areas of eastern North America and in the Great Lakes region during winter and tracked birds to breeding areas in Nunavut and northern Québec (fig. 10D). Allison and others (2013) summarized some of these same data from 14 long-tailed ducks marked in Nantucket Sound, Massachusetts. Mallory and others (2006) tracked the spring and fall migration paths of long-tailed ducks that wintered on western Lake Ontario. Apparent breeding areas for tracked individuals were in western Hudson Bay. 
Data from telemetry suggests separate western and eastern populations with a possible boundary somewhere in central Arctic Canada (Bartzen and others, 2017). Genetic information suggests expansion of a historical population to multiple locales across the northern distribution of the species. Broader-scale genetic information, similar to Sonsthagen and others (2019) for scoters, could help to clarify these patterns of population structure relative to the telemetry data for long-tailed ducks.

Braune and others (2005) examined stable isotopes from long-tailed ducks sampled on their breeding grounds across a broad portion of northern Canada and determined that stable isotopes were less useful than expected in discriminating breeding long-tailed ducks that overwintered in the Great Lakes versus coastal marine environments. Lawson (2006) also used stable isotope values of feathers and diet items to link a breeding area in northern Canada to wintering grounds and delineate populations. These authors determined that 14, 32, and 53 percent of longtailed ducks wintered on the Atlantic coast, Lake Ontario, and the Pacific coast, respectively. However, these authors also observed a high percentage of misclassification between Lake Ontario and the Pacific coast assignments and suggested that there is no clear $\delta 13 \mathrm{C}$ and $\delta 15 \mathrm{~N}$ isotopic gradient between Pacific and Atlantic Ocean for the long-tailed duck feathers sampled. 


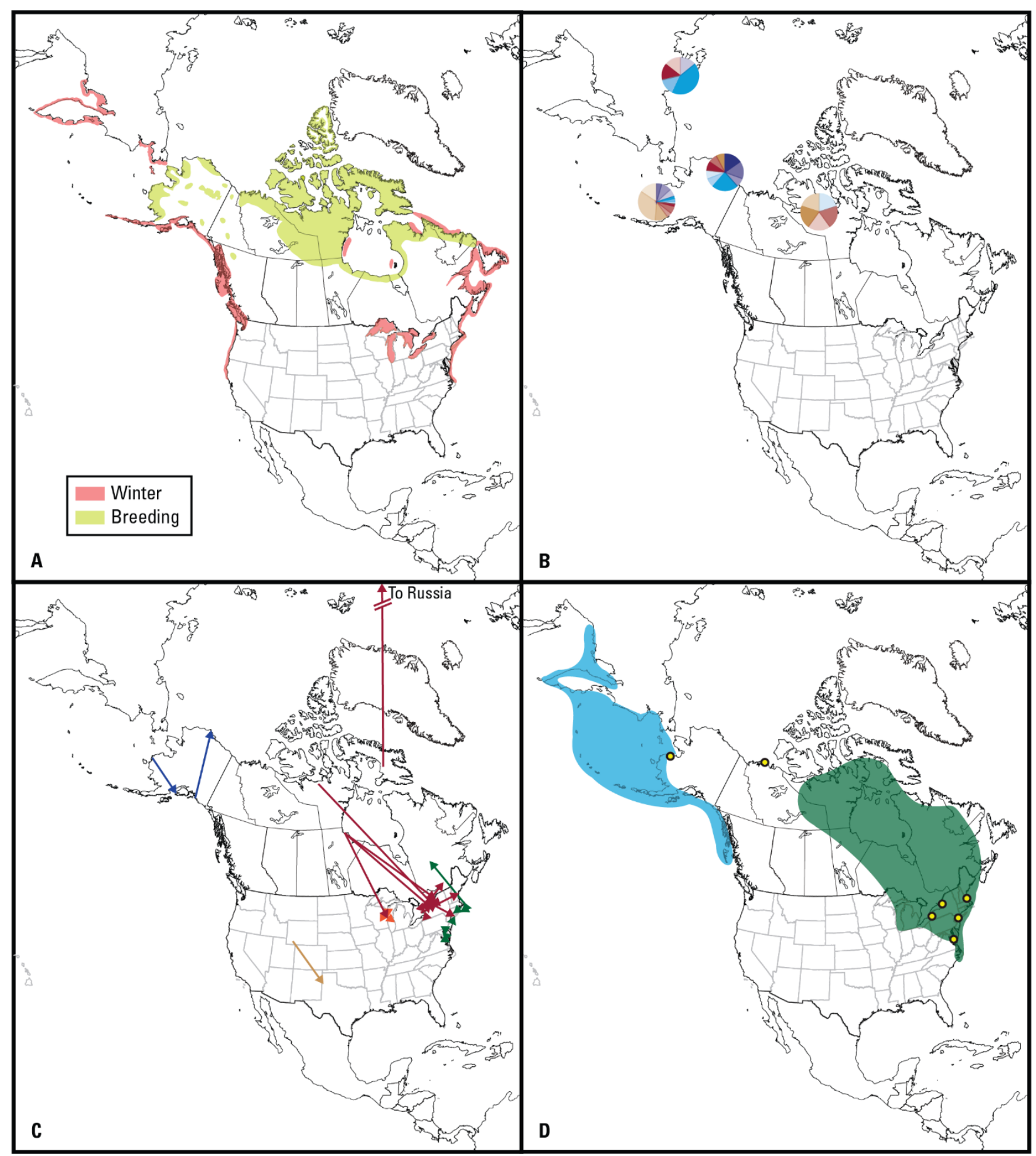

Figure 10. Maps showing long-tailed duck (Clangula hyemalis) information from $(A)$ geographic distribution, $(B)$ genetic, $(C)$ band recovery, and $(D)$ telemetry studies across North America. Yellow dots in $D$ show telemetry marking locales. Molting locations are not shown. Colors used in panels $A-D$ are for illustrative purposes only (see section, "Methods"). 


\section{Bufflehead (Bucephala albeola)}

\section{Geographic Distribution}

The bufflehead is a cavity nesting species with a breeding distribution that ranges across forested areas of Alaska, Canada, and the northern U.S. Wintering birds are widely distributed along both western and eastern coasts of North America, as well as inland areas of the U.S. and Mexico (fig. 11A; Gauthier, 2014).

Genetic

Pearce and others (2014) determined that there was no evidence for differentiation among regional groups of buffleheads from samples collected in Alaska, the Pacific Northwest, and the eastern region of North America. The authors acknowledged that their use of predominantly winter samples for bufflehead may have masked patterns of breeding-ground population genetic structure if wintering areas were composed of multiple breeding areas. However, the authors predicted that if wintering areas were composed of multiple breeding areas, then band recovery data would show patterns of differentiation between the western and eastern coasts of North America and this was not observed. There also was no evidence of Alaska-specific mtDNA haplotypes.

\section{Band Recovery}

Our band recovery data set contained 1,407 records (fig. 11C) and demonstrated a wide distribution of recoveries from banding areas in the western, central, and eastern regions of North America. Pearce and others (2014) used a smaller set of band recovery data and determined that winter recoveries of Bufflehead banded in British Columbia were distributed along the western coast of North America. Birds banded in Alaska may also winter within the geographic distribution of those banded in British Columbia. Pearce and others (2014) concluded that band recovery data provided no evidence of connectivity between particular breeding and wintering areas.

Telemetry

No buffleheads have been marked.

\section{Summary}

Results between genetic and band recovery data types were highly similar and suggest little evidence for population structure within buffleheads of North America. Genetic analysis of breeding samples across North America using more contemporary methods may provide new information on broad scale patterns of dispersal and connectivity. Telemetry would not likely be a useful method to gain additional information on connectivity between breeding and wintering areas for this species given the patterns observed for genetic and band recovery data. 




Figure 11. Maps showing bufflehead (Bucephala albeola) information from $(A)$ geographic distribution, $(B)$ genetic, $(C)$ band recovery, and $(D)$ telemetry studies across North America (no data). Molting locations are not shown. Colors used in panels $A-C$ are for illustrative purposes only (see section, "Methods"). 


\section{Common Goldeneye (Bucephala clangula)}

\section{Geographic Distribution}

Similar to the bufflehead, the common goldeneye is a cavity nesting species with a broad distribution that ranges across forested and other areas (during winter) of Alaska, Canada, and the northern U.S. (fig. 12A; Eadie and others, 1995).

\section{Genetic}

Pearce and others (2014) determined that the common goldeneye displays significant levels of population differentiation based on samples from Alaska, the Yukon, British Columbia, and Ontario.

\section{Band Recovery}

Our band recovery data set contained 2,436 records (fig. 12C) and demonstrated a wide distribution of recoveries from banding areas in western, central and eastern regions of North America. Pearce and others (2014) determined some evidence for regional differentiation in band recovery distributions. A map of band recoveries of common goldeneyes marked in Alaska did not overlap with other recovery distributions. Pearce and others (2014) determined that birds banded in Alberta and Saskatchewan had similar recovery distributions and recoveries from nearly all eastern banding areas (Maine, Québec, and New Brunswick) were distributed within the region of banding. Recoveries of common goldeneye banded in Minnesota and Ontario were predominantly distributed in the eastern North America. Home ranges for Minnesota- and Ontario-banded common goldeneye also overlapped in the Great Lakes and Chesapeake Bay regions.

\section{Telemetry}

No common goldeneyes have been marked.

\section{Summary}

Results between genetic and band recovery data types were similar, suggesting differentiation at larger scales despite the broad geographic distribution of this species in North America. A more in-depth analysis of existing band recovery data and genetic analysis of additional breeding or wintering samples could be conducted if more detailed information on regional population structure is needed. 


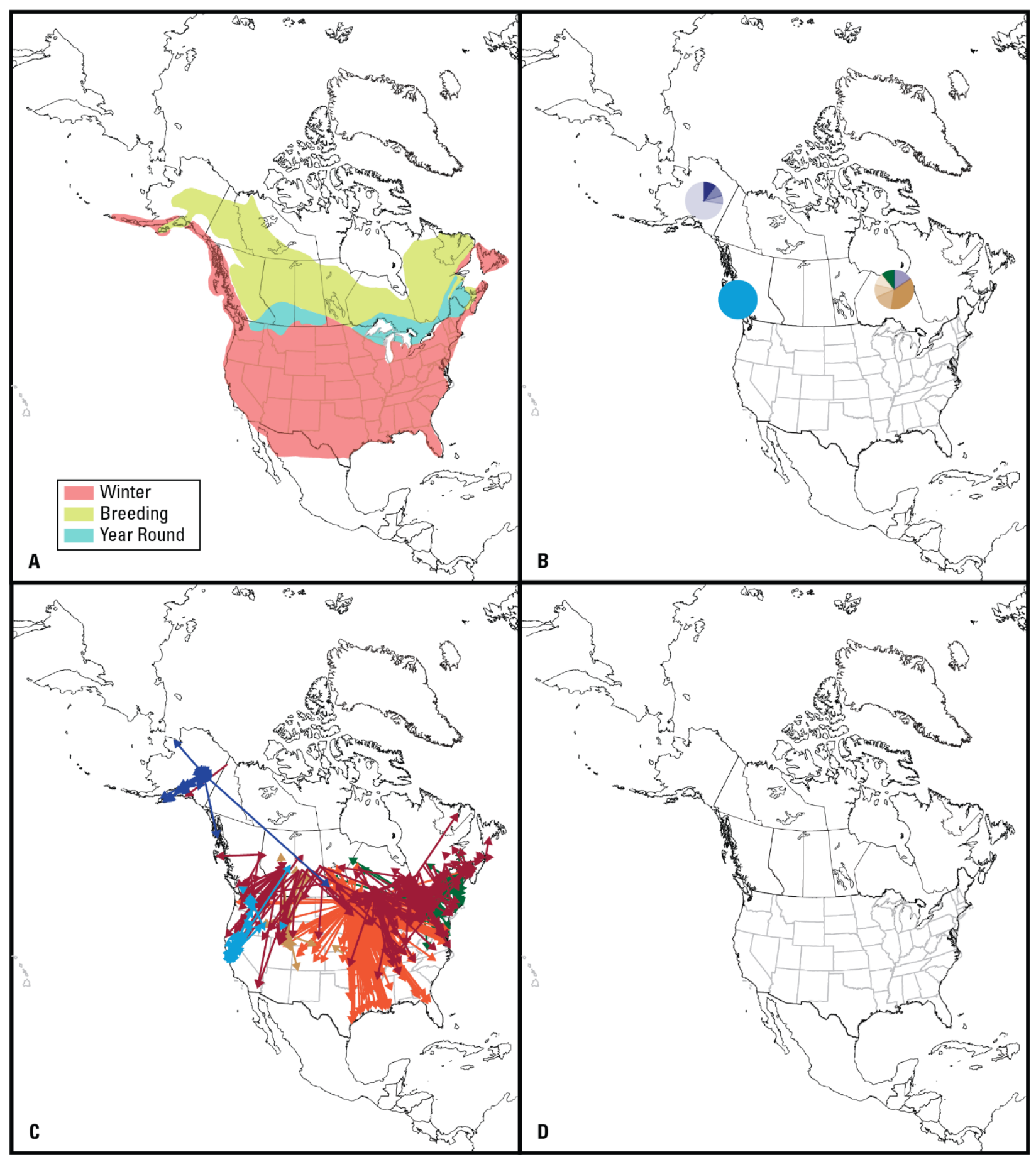

Figure 12. Maps showing common goldeneye (Bucephala clangula) information from $(A)$ geographic distribution, $(B)$ genetic, $(C)$ band recovery, and $(D)$ telemetry studies across North America (no data). Molting locations are not shown. Colors used in panels $A-C$ are for illustrative purposes only (see section, "Methods"). 


\title{
Barrow's Goldeneye (Bucephala islandica)
}

\author{
Genetic Distribution
}

The Barrow's goldeneye is a cavity nesting species with a restricted breeding and wintering distribution in North America (fig. 13A; Eadie and others, 2000). In eastern North America, Barrow's goldeneyes have more limited distribution than in the western part of the continent.

\section{Genetic}

Pearce and others (2014) determined that Barrow's goldeneye populations are genetically differentiated across North America, but differences are slight, with only one or two base-pair substitutions separating mtDNA variants.

\section{Band Recovery}

Our band recovery data set contained 853 records (fig. 13C), with few records from the eastern region of North America. Band recoveries from birds marked in southern British Columbia, Canada, have a distribution that is largely restricted to that same region, but many birds have also been recovered throughout the west coast of the U.S. and even into the upper Midwest. Pearce and others (2014) used a smaller set of band recovery data and similarly found no overlap among birds banded in Alaska and British Columbia, but observed some individual recovery locations within $450 \mathrm{~km}$ of each other in southeast Alaska and coastal British Columbia. Pearce and others (2014) also determined that most Alaska band recoveries were concentrated around Kodiak Island and the northern portion of the Gulf of Alaska.

\section{Telemetry}

A total of 272 transmitters have been deployed in Barrow's goldeneye: 267 by Boyd and Esler (2012) and 5 by Savard and Robert (2013). In western North America, Boyd and Esler (2012) marked Barrow's goldeneyes in four locations (fig. 13D): southern British Columbia near Vancouver, southcentral British Columbia, western Alberta, and Prince William Sound, Alaska. Barrow's goldeneyes marked in British Columbia and Alberta all bred and wintered within the same location, from northern Washington to southeast Alaska. In contrast, birds marked in Prince William Sound appeared to constitute a separate population as movements of birds showed a completely different migratory pattern compared to birds marked in British Columbia and Alberta. In eastern North America, Savard and Robert (2013) determined that birds moved a relatively short distance north to molting areas after breeding before returning to wintering areas in the St. Lawrence estuary of southern Québec (fig. 13D).

\section{Summary}

We observed very similar patterns for genetic, band recovery and telemetry data for Barrow's goldeneyes that confirm not only the disjunct geographic distribution across North America, but additional population structure between Alaska and British Columbia. 


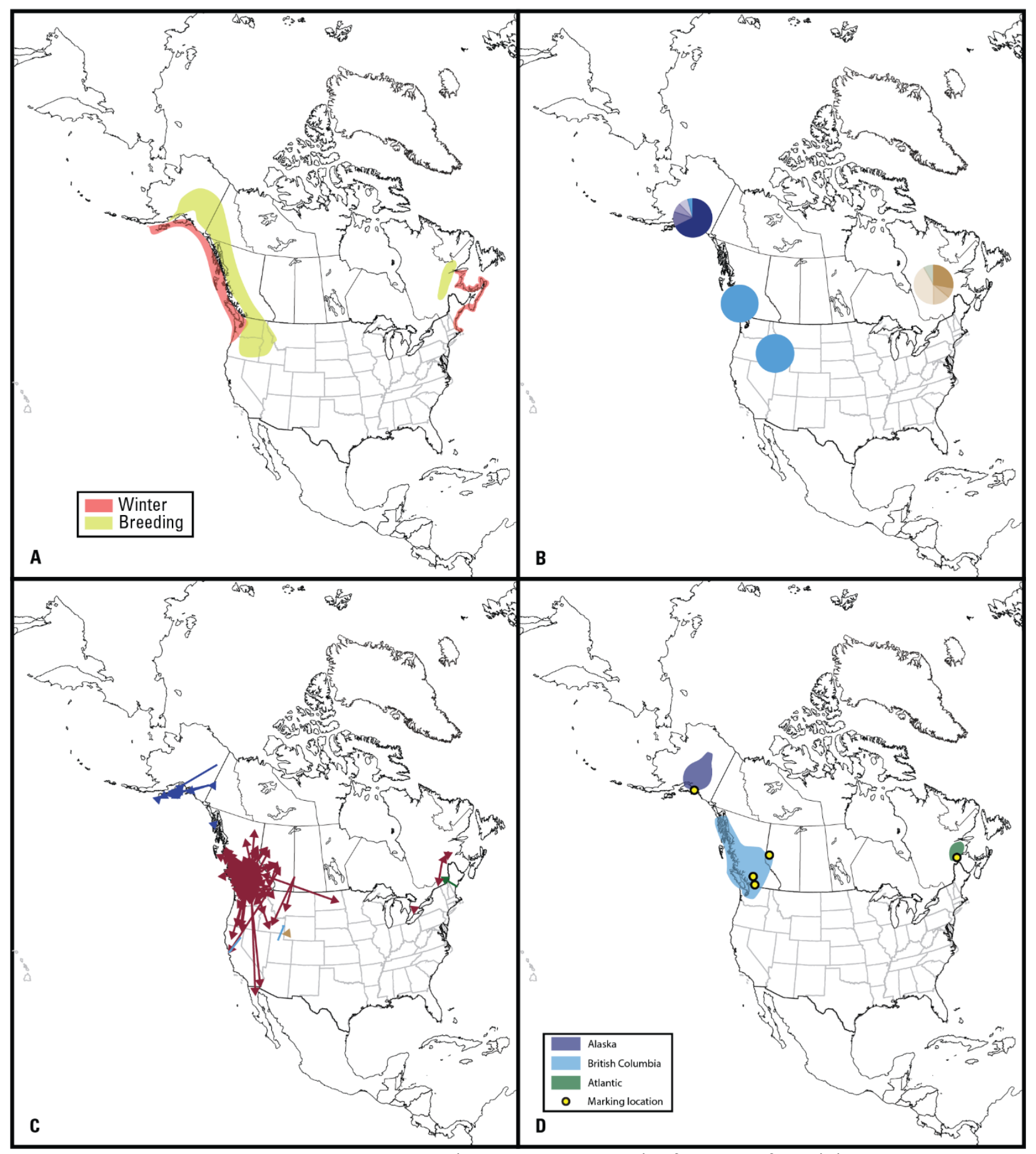

Figure 13. Maps showing Barrow's goldeneye (Bucephala islandica) information from $(A)$ geographic distribution, $(B)$ genetic, $(C)$ band recovery, and $(D)$ telemetry studies across North America. Yellow dots in $D$ show telemetry marking locales. Molting locations are not shown. Colors used in panels $A-D$ are for illustrative purposes only (see section, "Methods"). 


\section{Hooded Merganser (Lophodytes cucullatus)}

\section{Geographic Distribution}

The hooded merganser is resident throughout the year in broad areas of the Pacific Northwest of British Columbia, Canada, and Washington and Oregon in the northwestern U.S., and much of the eastern half of the continental U.S. (fig. 14A; Dugger and others, 2009). The species is also known to breed across the southern portion of eastern Canada and central Canada (Dugger and others, 2009). The overall distribution is apparently disjunct, with no evidence for areas of sympatry by birds that breed or winter on the western and eastern portions of North America.

\section{Genetic}

Pearce and others (2008) determined that there was little evidence for an overall genetic difference between western and eastern regions of North America hooded mergansers despite the disjunct geographic range of the species and evidence for high breeding site fidelity.

\section{Band Recovery}

Our band recovery data set included 1,808 records with most from the central and eastern portion of North America (fig. 14C). Few band recoveries exist from the western regions of North America. Pearce and others (2008) examined a smaller set of band recoveries and observed a general north-south distribution of recoveries, especially for the Missouri banding area. Additionally, these authors detected direct band recoveries of juveniles far to the west of Missouri in Wyoming and Washington, suggestive of dispersal.

\section{Telemetry}

No hooded mergansers have been marked.

\section{Summary}

This species has a disjunct geographical distribution and limited evidence for population connectivity across North America based on band recovery data. Pearce and others (2008) found little evidence for distinct western and eastern populations across North America, which may result from small scale dispersal and gene flow. Some band recovery records also suggest dispersal within and among regions. Refined estimates of continental connectivity could be accomplished with more contemporary genetic analyses. 


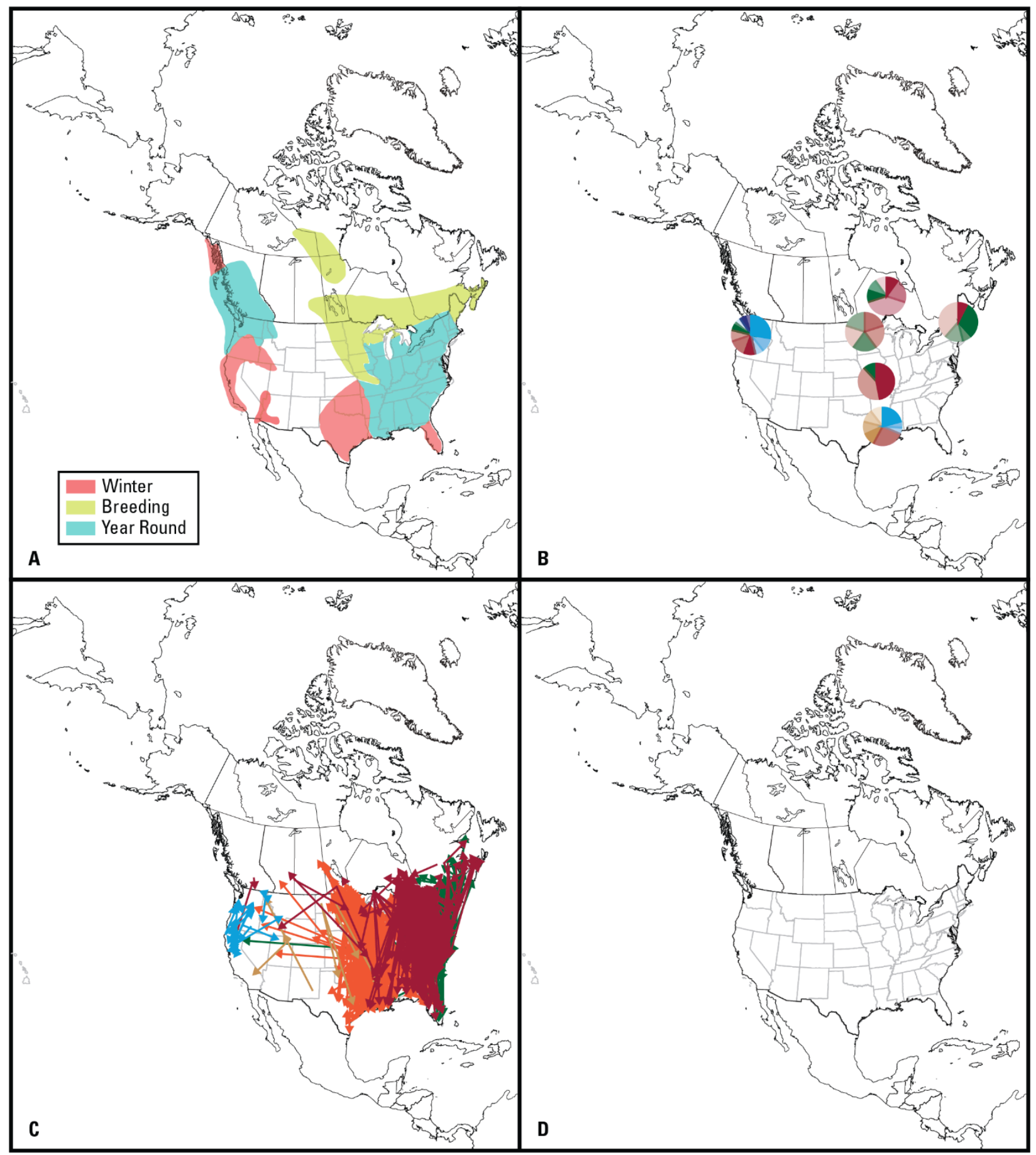

Figure 14. Maps showing hooded merganser (Lophodytes cucullatus) information from ( $A$ ) geographic distribution, $(B)$ genetic, $(C)$ band recovery, and $(D)$ telemetry studies across North America (no data). Molting locations are not shown. Colors used in panels $A-C$ are for illustrative purposes only (see section, "Methods"). 


\section{Common Merganser (Mergus merganser)}

\section{Geographic Distribution}

The common merganser is a cavity-nesting species with a broad breeding and wintering distribution in North America (fig. 15A; Pearce and others, 2015) and the species is known to remain at high latitudes, such as in Alaska, throughout the winter as long as open water is available (Pearce and Petersen, 2009).

\section{Genetic}

Pearce and others (2009b) and Peters and others (2012) determined that breeding groups within North America were highly structured genetically for mtDNA, likely a result of female philopatry. Common mergansers breeding in western and eastern North America were strongly differentiated at both the regional level, and at finer scales. North America samples clustered into three major mtDNA haplotype groups: (1) Beringia, including samples from interior and western Alaska, the Aleutian Islands, and Magadan, Russia; (2) south central and southeastern Alaska and British Columbia; and (3) Washington, western Ontario, and eastern North America.

\section{Band Recovery}

Our band recovery data set included 308 records with the vast majority occurring in the eastern portion of North America (fig. 15C). Using a smaller set of banding data, Pearce and others $(2005 ; 2009 b)$ determined that there was evidence for geographic and sex-specific variation in survival and migratory tendency across eastern North America.

\section{Telemetry}

Pearce and Petersen (2009) marked fledgling common mergansers in southcentral Alaska and determined that birds remained in this region throughout the post-fledging fall and early winter months (fig. 15D). Telemetry units did not last long enough to determine subsequent breeding and wintering locations, although two birds were tracked to the following summer. Some individuals have been marked in eastern North America, but data are not yet publicly available.

\section{Summary}

Given the high degree of genetic differentiation across regions of North America in common mergansers, regional populations could be identified through additional genetic assessments. Banding data in the western portion of North America could also provide more insights into the geographic and sex-specific variation in survival and migratory tendency across the continent. 


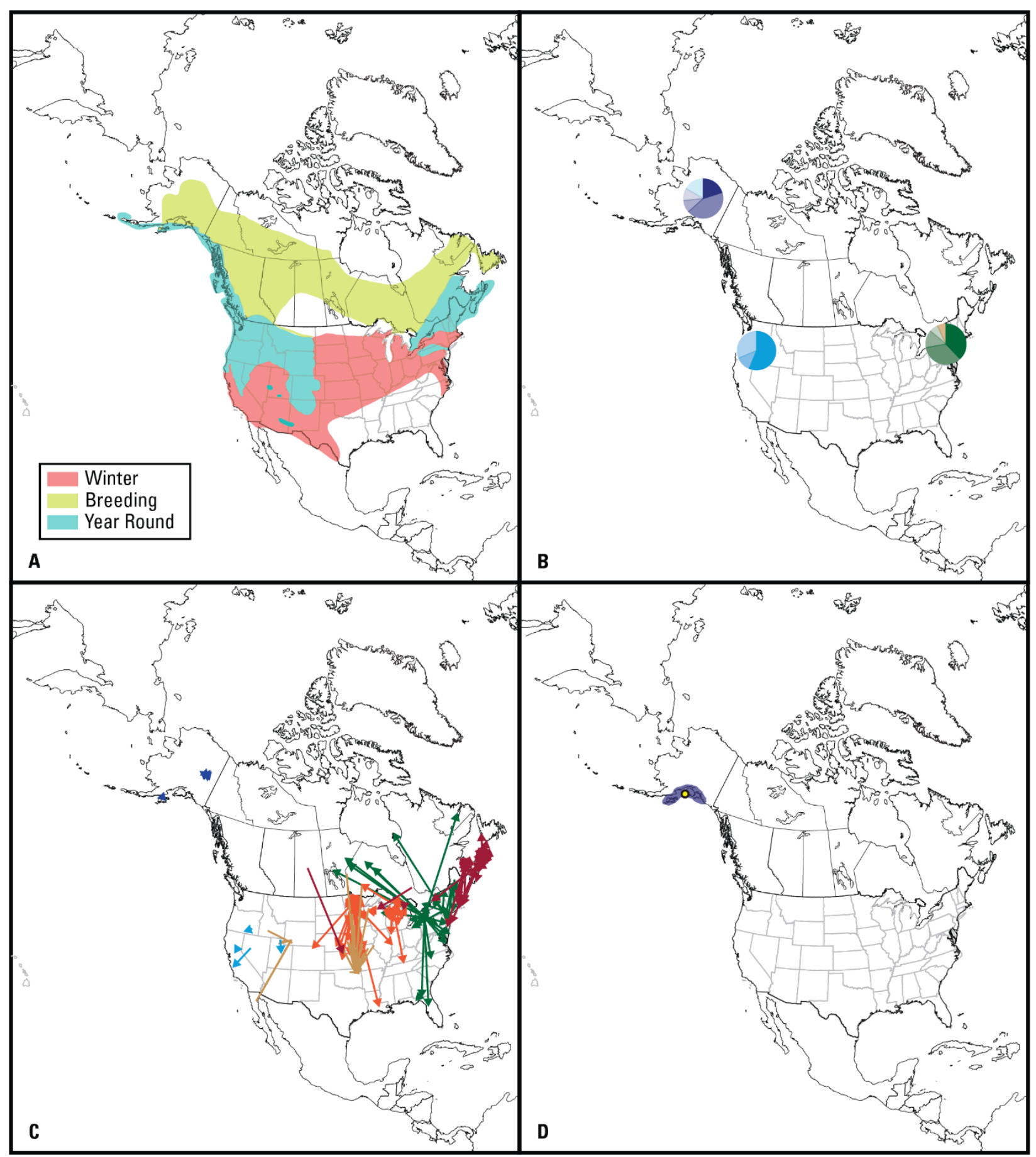

Figure 15. Maps showing common merganser (Mergus merganser) information from $(A)$ geographic distribution, $(B)$ genetic, $(C)$ band recovery, and $(D)$ telemetry studies across North America. Yellow dots in $D$ show telemetry marking locales. Molting locations are not shown. Colors used in panels $A-D$ are for illustrative purposes only (see section, "Methods"). 


\section{Red-Breasted Merganser (Mergus serrator)}

\section{Geographic Distribution}

The red-breasted merganser is a ground nesting species with a breeding distribution that spans northern areas of North America (fig. 16A; Craik and others, 2015). During winter, birds are distributed along coasts of North America, including the Great Lakes region.

Genetic

Pearce and others (2009b) determined that the red-breasted merganser exhibits low levels of population differentiation across North America and has a star-like patter in the mtDNA haplotype network, likely due to post-Pleistocene range expansion and population growth. However, Pearce and others (2009b) determined that winter samples from hunter-harvested birds from Alaska and the Pacific and Atlantic Ocean regions of North America suggests that birds wintering on the two opposite coasts are distinct.

\section{Band Recovery}

Our band recovery data contained 34 records (fig. 16C), with nearly all occurring along the eastern coast of North America.

Telemetry

No red-breasted mergansers have been marked.

\section{Summary}

There may be a genetic difference between western and eastern North America populations of red-breasted mergansers at a broad-scale. Additional genetic analyses involving more contemporary methods and technologies could assist in refining these findings. Some banding effort and telemetry work could also help understand migratory patterns and assess population delineation. 


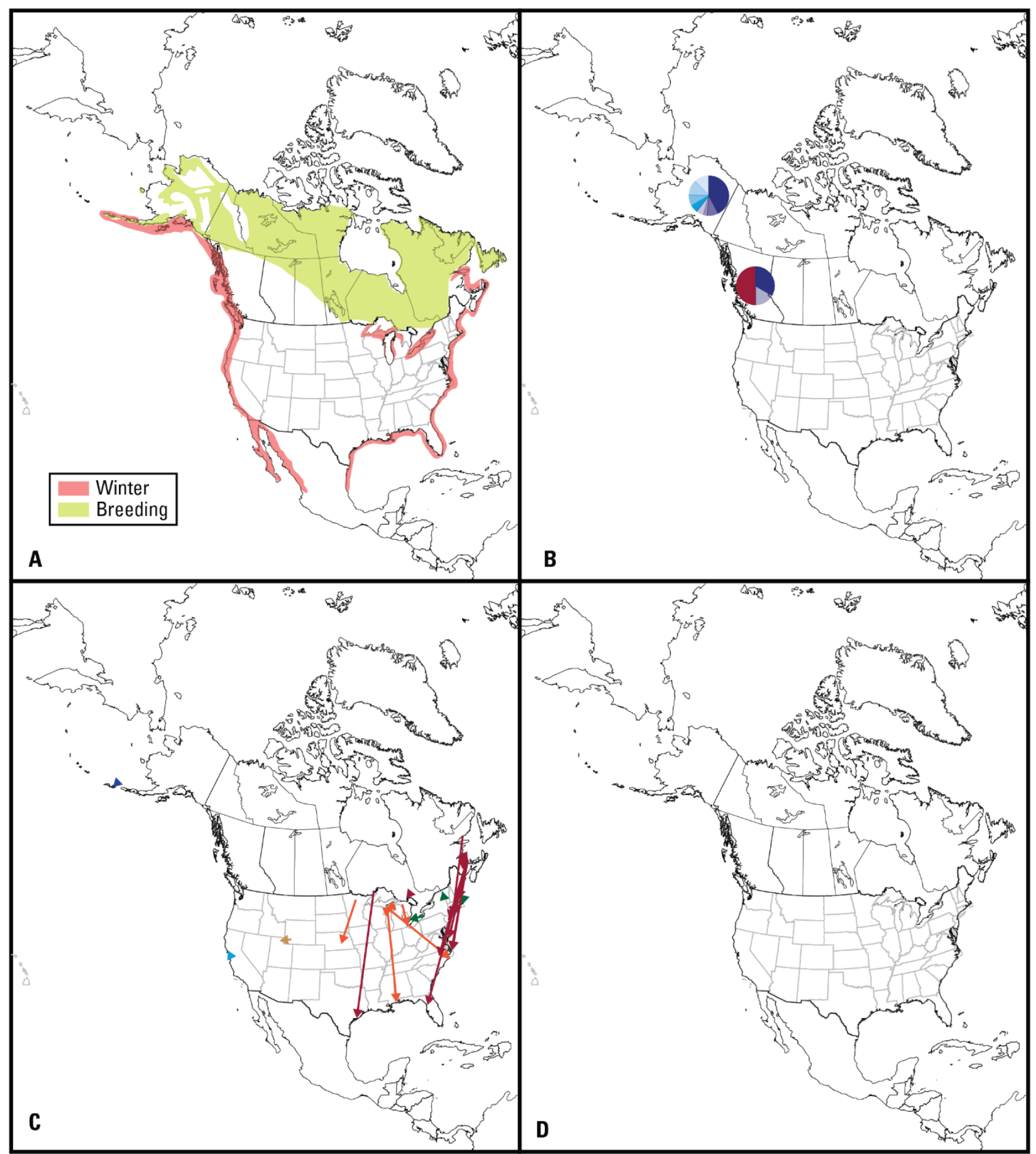

Figure 16. Maps showing red-breasted merganser (Mergus serrator) information from $(A)$ geographic distribution, $(B)$ genetic, $(C)$ band recovery, and $(D)$ telemetry studies across North America (no data). Molting locations are not shown. Colors used in panels $A-C$ are for illustrative purposes only (see section, "Methods"). 


\section{Discussion}

The maps in this report offer graphical depictions of geographic distribution of 13 species of sea ducks and their migratory and likely population patterns, based on genetic, band recovery, and telemetry data sets. For most species, these perspectives have not been previously combined in a way that allows for visual assessment of broad patterns. Our intent with these maps was to document what information has been gathered and identify where additional information is or is not needed for a particular species and marker type. We also sought to determine species with well-defined regional populations that may need monitoring and management actions at that scale.

In North America, waterfowl status and trend monitoring and management actions typically take place within the four geographically defined migratory flyways: Pacific, Central, Mississippi, and Atlantic. Although flyways are convenient geographic and management units that represent general waterfowl migration corridors, they may not encompass those species that move east-west across North America or the dispersal events that take place across the geographic range of a species. In some cases, a single population may occur within multiple flyways, whereas in other cases multiple populations may occur within a single flyway.

Additionally, migratory flyways of several species extend beyond North America to include Russia and Greenland.

Much of the recent sea duck research summarized in the maps in this report provides a range of information on population delineation. Some of this information may be sufficient to move forward with formal delineation, which could then assist with addressing the scope and scale of management issues that need to be defined for a particular species or population. However, applying any sort of management prescription without understanding the population structure to which it is applied makes it impossible to measure the outcome and validate the management action (Flint, 2015). Thus, we hope that these maps will serve as visual null and alternative hypotheses about levels of population delineation.

However, there are some limitations to the maps and conclusions drawn from them. Using these maps for finer-scale delineation may not be warranted due to the poor resolution of some of the information. For example, geographic range maps show greater distributional extent than do polygons of telemetry and banding data because birds have not been marked throughout all portions of their known ranges. Although we removed most adult birds from late summer time frames during which the flightless molt occurs, some molt locations may still exist in the data set used for the band recovery maps. Additionally, we identified some questionable recoveries that, when checked against data at the USGS Bird Banding Laboratory, were determined to likely be erroneous recovery submissions. Thus, assessments of band recovery data for inferring fine scale population movements or delineation questions requires careful review of final data. Telemetry maps generated in this report are based on figures from published accounts of satellite transmitter studies. Much of the data from these publications are not available, but public telemetry data release and visualization platforms, such as Movebank (Wikelski and Kays, 2019) and the USGS Alaska Science Center wildlife tracking data collection (U.S. Geological Survey Alaska Science Center, 2019), are providing sites and standardized methods for public release of these data. Lastly, much more telemetry data exist for several species, particularly in western North America, but are not yet publicly available.

The maps in this report highlight where information gaps remain, where no additional application of a certain marker type is needed to address questions about broad scale migration 
patterns or population structure, and where future hypothesis-driven research could be undertaken to fill remaining information gaps. For example, telemetry and genetic information from the three scoter species demonstrates a need for quantitative assessment of telemetry information to describe basic migration patterns of the western population of black scoters as well as degree of sympatry for surf and white-winged scoter. Once known, abundance and trend data from spring or winter monitoring surveys from western and eastern North America could then take into account the likely proportion of total counts that may come from more than one continental breeding population. Similarly, all three independent data sets are robust for species such as the Barrow's goldeneye and match much of the geographic range map for this species. Thus, monitoring and management plans could be developed for specific regional populations of Barrow's goldeneye if needed. In contrast, more information is needed for some species before regional populations can be delineated, such as black scoter and long-tailed duck.

We hope that these maps will provide a starting point for future hypothesis-driven research to fill remaining information gaps and refine population boundaries, particularly if expensive and invasive telemetry units are being considered. For example, data from genetics and band recovery for species such as the bufflehead suggest that use of telemetry data would not enhance our understanding of continental population delineation due to the broad dispersal patterns in this species. Additional and newer genetic work might be the most appropriate and least invasive next step in many cases for species and populations of sea ducks. 


\section{Acknowledgements}

We wish to acknowledge the many people who banded birds and reported bands when recovered. We thank Danny Bystrak (U.S. Geological Survey [USGS]) and Matt Rogosky (USGS) for assisting with banding data. Cindy Wood (Environment and Climate Change Canada), Dan Esler (USGS), Susan De La Cruz (USGS), David Ward (USGS), Dirk Derksen (USGS retired), Bill Gibbs (USGS) and Jeffery Suwak (USGS) provided comments and reviews on earlier versions of this report.

\section{References Cited}

Abraham, K.F., and Finney, G.H., 1986, Eiders of the eastern Canadian Arctic, in Reed, A., ed., Eider ducks in Canada - Canadian Wildlife Service Report Series No. 47: Ottawa, Ontario, Canada, p. 55-73.

Allison, T.D., Perkins, S., Stryjewski, K.F., and Sorenson, M.D., 2013, Determining nocturnal locations, breeding ground locations, and genetic structure of long-tailed ducks wintering in Nantucket Sound: U.S. Dept. of the Interior, Bureau of Ocean Energy Management, Final Report 2013-01141, 33 p., accessed May 9, 2019, at https://marinecadastre.gov/espis/\#/search/study/23163.

Amundson, C.L., Flint, P.L., Stehn, R.A., Platte, R., Wilson, H.M., Larned, W.W., and Fischer, J.B., 2019, Spatio-temporal population change of Arctic-breeding waterbirds on the Arctic Coastal Plain of Alaska: Avian Conservation and Ecology, v. 14, no. 1, p. 18.

Anderson, E.M., Dickson, R.D., Lok, E.K., Palm, E.C., Savard, J.-P.L., Bordage, D., and Reed, A., 2015, Surf Scoter (Melanitta perspicillata), version 2.0, in Rodewald, P.G., ed., The birds of North America: Cornell Lab of Ornithology, Ithaca, New York, accessed July 2, 2019, at: https://birdsna.org/Species-Account/bna/species/sursco/introduction

Bartzen, B.A., Dickson, D.L., and Bowman, T.D., 2017, Migration characteristics of long-tailed ducks (Clangula hyemalis) from the western Canadian Arctic: Polar Biology, v. 40, no. 5, p. 1085-1099.

Batt, B.D., 2016, Ecology and conservation of North American sea ducks: The Condor, v. 118, no. 2, p. 447-448.

Beuth, J.M., McWilliams, S.R., Paton, P.W.C., and Osenkowski, J.E., 2017, Habitat use and movements of common eiders wintering in southern New England: The Journal of Wildlife Management, v. 81, no. 7, p. 1276-1286.

Boyd, S., and Esler, D., 2012, Migration and habitat use of Pacific Barrow's goldeneyes: Simon Frasier University, accessed May 9, 2019, at http://www.sfu.ca/biology/wildberg/CWESeaducksfolder/BAGOwebpage/BAGOMigration Home.html.

Bordage, D., and Savard, J.-P.L., 2011, Black scoter (Melanitta americana), version 2.0, in Poole, A.F., ed., The birds of North America: Cornell Lab of Ornithology, Ithaca, NY, USA, accessed July 2, 2019, at https://birdsna.org/Species-

Account/bna/species/blksco2/introduction.

Braune, B.M., Hobson, K.A., and Malone, B.J., 2005, Regional differences in collagen stable isotope and tissue trace element profiles in populations of long-tailed duck breeding in the Canadian Arctic: The Science of the Total Environment, v. 346, no. 1-3, p. 156-168. 
Brodeur, S., Savard, J.-P.L., Robert, M., Laporte, P., Lamothe, P., Titman, R.D., Marchand, S., Gilliland, S., and Fitzgerald, G., 2002, Harlequin duck Histrionicus population structure in eastern Neartic: Journal of Avian Biology, v. 33, no. 2, p. 127-137.

Brown, P.W., and Fredrickson, L.H., 2019, White-winged Scoter (Melanitta deglandi), version 1.1., in Rodewald, P.G., ed., The birds of North America: Cornell Lab of Ornithology, Ithaca, NY, USA, accessed July 2, 2019, at https://birdsna.org/Species-

Account/bna/species/whwsco4/introduction/.

Chubbs, T.E., Trimper, P.G., Humphries, G.W., Thomas, P.W., Elson, L.T., and Laing, D.K., 2008, Tracking seasonal movements of adult male Harlequin Ducks from central Labrador using satellite telemetry in Robertson, G.J., Thompson, P.W. Savard, J-P.L., and Hobson, K.A., eds., Harlequin ducks in the northwest Atlantic: Waterbirds, v. 31 (Special Publication 2), p. 173-182.

Craik, S., Pearce, J.M., and Titman, R.D., 2015, Red-breasted Merganser (Mergus serrator), version 2.0, in Poole, A.F., ed., The Birds of North America: Cornell Lab of Ornithology, Ithaca, NY, USA, accessed July 2, 2019, at https://birdsna.org/Species-

Account/bna/species/rebmer/introduction.

De La Cruz, S.E.W., Takekawa, J.Y., Wilson, M.T., Nysewander, D.R., Evenson, J.R., Esler, D., Boyd, W.S., and Ward, D.H., 2009, migration routes and chronology of surf scoters (Melanitta perspicillata) —A synthesis of Pacific coast studies: Canadian Journal of Zoology, v. 87, no. 11, p. 1069-1086.

Derksen, D.V., Savard, J.-P.L., Esler, D., and Eadie, J.M., 2015, Introduction, in Savard, J.-P.L., Derksen, D.V., Esler, D., and Eadie, J.M., eds., Ecology and Conservation of North American Sea Ducks-Studies in Avian Biology v. 46, p. xvii-xxii.

Descamps, S., Gilchrist, H.G., Bety, J., Buttler, E.I., and Forbes, M.R., 2009, Costs of reproduction in a long-lived bird-Large clutch size is associated with low survival in the presence of a highly virulent disease: Biology Letters, v. 5, no. 2, p. 278-281.

Dickson, D.L., 2012a, Movement of king eiders from breeding grounds on Banks Island, NWT, to moulting and wintering areas: Technical Report Series No. 516. Canadian Wildlife Service, Edmonton, Alberta, accessed May 9, 2019, at http://publications.gc.ca/site/eng/406720/publication.html.

Dickson, D.L., 2012b, Seasonal movement of Pacific common eiders breeding in arctic Canada. Technical Report Series 521, Canadian Wildlife Service, Edmonton, Alberta, accessed May 9, 2019, at http://publications.gc.ca/site/eng/9.573220/publication.html

Dugger, B.D., Dugger, K.M., and Fredrickson, L.H., 2009, Hooded Merganser (Lophodytes cucullatus), version 2.0, in Poole, A.F., ed., The Birds of North America: Cornell Lab of Ornithology, Ithaca, NY, USA, accessed July 2, 2019, at: https://birdsna.org/SpeciesAccount/bna/species/hoomer/introduction

Eadie, J.M., Mallory, M.L., and Lumsden, H.G., 1995, Common Goldeneye (Bucephala clangula), version 2.0., in Poole, A.F., and Gill, F.B., eds., The Birds of North America: Cornell Lab of Ornithology, Ithaca, NY, USA, accessed July 2, 2019, at: https://birdsna.org/Species-Account/bna/species/comgol/introduction/

Eadie, J.M., Savard, J.-P.L., and Mallory, M.L., 2000, Barrow's Goldeneye (Bucephala islandica), version 2.0, in Poole, A.F., and Gill, F.B., eds., The Birds of North America: Cornell Lab of Ornithology, Ithaca, NY, USA, accessed July 2, 2019, at: https://birdsna.org/Species-Account/bna/species/bargol/introduction/ 
Esler, D., Iverson, S.A., and Rizzolo, D.J., 2006, Genetic and demographic criteria for defining population units for conservation-The value of clear messages: The Condor, v. 108, no. 2, p. 480-483. https://doi.org/10.1093/condor/108.2.480.

Esler, D., Flint, P.L., Derksen, D.V., Savard, J.-P.L., and Eadie, J.M., 2015, Conclusions, synthesis, and future directions, in Savard, J.-P.L., Derksen, D.V., Esler, D., and Eadie, J.M., eds., Ecology and Conservation of North American Sea Ducks-Studies in Avian Biology v. 46, p. 417-467.

Flint, P.L., 2015, Population dynamics of sea ducks - The causes, consequences, evolution, and management of variation, in Savard, J.-P.L., Derksen, D.V., Esler, D., and Eadie, J.M., eds., Ecology and Conservation of North American Sea Ducks-Studies in Avian Biology v. 46, p. 63-96.

Gauthier, G., 2014, Bufflehead (Bucephala albeola), version 2.0. in Poole, A.F., ed., The Birds of North America: Cornell Lab of Ornithology, Ithaca, NY, USA, accessed July 2, 2019, at: https://birdsna.org/Species-Account/bna/species/buffle/introduction/

Gilliland, S.G., Gilchrist, H.G., Rockwell, R.F., Robertson, G.J., and Savard, J.-P.L., 2009, Evaluating the sustainability of harvest among northern common eiders Somateria mollissima borealis in Greenland and Canada: Wildlife Biology, v. 15, no. 1, p. 24-36. https://doi.org/10.2981/07-005.

Goudie, R.I., Robertson, G.J., and Reed, A., 2000, Common eider (Somateria mollissima), version 2.0, in Poole, A.F., and Gill, F.B., eds., The Birds of North America: Cornell Lab of Ornithology, Ithaca, NY, USA, accessed July 2, 2019, at: https://birdsna.org/SpeciesAccount/bna/species/comeid/introduction

Houston, C.S., and Brown, P.W., 1983, Recoveries of Saskatchewan-banded white-winged scoters, Melanitta fusca: Canadian Field Naturalist, v. 97, p. 454-455.

Iverson, S.A., Esler, D., and Rizzolo, D.J., 2004, philopatry of harlequin ducks in Prince William Sound, Alaska - The Condor: Ornithological Applications, v. 106, p. 711-715.

Iverson, S.A., Forbes, M.R., Simard, M., Soos, C., and Gilchrist, H.G., 2016, Avian cholera emergence in Arctic-nesting northern common eiders-Using community-based, participatory surveillance to delineate disease outbreak patterns and predict transmission risk: Ecology and Society, v. 21, no. 4, p. 12. https://doi.org/10.5751/ES-08873-210412.

King, J.G., 1963, Duck banding in Arctic Alaska: The Journal of Wildlife Management, v. 27, no. 3, p. 356-362. https://doi.org/10.2307/3798507.

Lamb, J.S., Paton, P.W.C., Osenkowski, J.E., Badzinski, S.S., Berlin, A.M., Bowman, T., Dwyer, C., Fara, L.J., Gilliland, S.G., Kenow, K., Lepage, C., Mallory, M.L., Olsen, G.H., Perry, M.C., Petrie, S.A., Savard, J.-P.L., Savoy, L., Schummer, M., Spiegel, C.S., and McWilliams, S.R., 2019, Spatially-explicit network analysis reveals multi-species annual-cycle movement patterns of sea ducks: https://doi.org/10.1002/eap.1919

Lanctot, R., Goatcher, B., Scribner, K., Talbot, S.L., Pierson, B., Esler, D., and Zwiefelhofer, D., 1999, Harlequin ducks recovery from the Exxon Valdez oil spill-A population genetics perspective: The Auk, v. 116, no. 3, p. 781-791. https://doi.org/10.2307/4089338.

Lawson, S.L., 2006, Comparative reproductive strategies between long-tailed ducks and king eiders at Karrak Lake, Nunavut: use of energy resources during the nesting season. M.S. Thesis, University of Saskatchewan, Saskatoon, Canada, accessed May 9, 2019, at: https://harvest.usask.ca/handle/10388/etd-09202006-233329 
Mallory, M.L., Akearok, J., North, N.R., Weseloh, D.V., and Lair, S., 2006, Movements of Long-tailed Ducks wintering on Lake Ontario to breeding areas in Nunavut, Canada: The Wilson Journal of Ornithology, v. 118, no. 4, p. 494-501. https://doi.org/10.1676/05-068.1.

Meattey, D.E., McWilliams, S.R., Paton, P.W.C., Lepage, C., Gilliland, S.G., Savoy, L., Olsen, G.H., and Osenkowski, J.E., 2018, Annual cycle of white-winged scoters (Melanitta fusca) in eastern North America-Migratory phenology, population delineation, and connectivity: Canadian Journal of Zoology, v. 96, no. 12, p. 1353-1365. https://doi.org/10.1139/cjz-2018$\underline{0121 .}$.

Mehl, K.R., Alisauskas, R.T., Hobson, K.A., and Kellett, D.K., 2004, To winter east or west? Heterogeneity in winter philopatry in a central-arctic population of king eiders: The Condor, v. 106, no. 2, p. 241-251. https://doi.org/10.1093/condor/106.2.241.

Mosbech, A., Dano, R.S., Merkel, F., Sonne, C., Gilchrist, G., and Flagstad, A., 2006a, Use of satellite telemetry to locate key habitats for king eiders Somateria spectabilis in West Greenland, in Boere, G.C., Galbraith, C.A., and Stroud, D.A., eds., Waterbirds around the world: Edinburgh, The Stationery Office, p. 769-776.

Mosbech, A., Gilchrist, G., Merkel, F., Sonne, C., Flagstad, A., and Nyegaard, H., 2006b, Yearround movements of northern common eiders Somateria mollissima borealis breeding in Arctic Canada and West Greenland followed by satellite telemetry: Ardea, v. 94, p. 651-667.

O'Connor, M., 2008, Surf scoter (Melanitta perspicillata) ecology on spring staging grounds and during the flightless period. Thesis, McGill University, Montreal, QC, accessed May 20, 2019, at: http://digitool.library.mcgill.ca/R/?func=dbin-jump-

full\&object_id=112548\&local_base=GEN01-MCG02

Pearce, J.M., Talbot, S.L., Pierson, B.J., Petersen, M.R., Scribner, K.T., Lynne Dickson, D., and Mosbech, A., 2004, Lack of spatial genetic structure among nesting and wintering king eiders - The Condor: Ornithological Applications, v. 106, p. 229-240.

Pearce, J.M., Reed, J.A., and Flint, P.L., 2005, Geographic variation in survival and migratory tendency among North American common mergansers: Journal of Field Ornithology, v. 76, no. 2, p. 109-118. https://doi.org/10.1648/0273-8570-76.2.109.

Pearce, J.M., and Talbot, S.L., 2006, Demography, genetics, and the value of mixed messages:

The Condor, v. 108, no. 2, p. 474-479. https://doi.org/10.1093/condor/108.2.474.

Pearce, J.M., Blums, P., and Lindberg, M.S., 2008, Site fidelity is an inconsistent determinant in population structure of the hooded merganser (Lophodytes cucullatus) -Evidence from genetic, mark-recapture, and comparative data: The Auk, v. 125, no. 3, p. 711-722. https://doi.org/10.1525/auk.2008.07154.

Pearce, J.M., and Petersen, M.R., 2009, Post-fledging movements of juvenile common mergansers (Mergus merganser) in Alaska as inferred by satellite telemetry: Waterbirds, v. 32, no. 1, p. 133-137. https://doi.org/10.1675/063.032.0116.

Pearce, J.M., Zwiefelhofer, D., and Maryanski, N., 2009a, Mechanisms of population heterogeneity among molting Common Mergansers on Kodiak Island, Alaska-Implications for genetic assessments of migratory connectivity: The Condor, v. 111, no. 2, p. 283-293. https://doi.org/10.1525/cond.2009.080043.

Pearce, J.M., McCracken, K.G., Christensen, T.K., and Zhuravlev, Y.N., 2009b, Migratory patterns and population structure among breeding and wintering red-breasted mergansers (Mergus serrator) and common mergansers (M. merganser): The Auk, v. 126, no. 4, p. 784798. https://doi.org/10.1525/auk.2009.08182. 
Pearce, J.M., Eadie, J.M., Savard, J.-P.L., Christensen, T.K., Berdeen, J., Taylor, E.J., Boyd, S., Einarsson, Á., and Talbot, S.L., 2014, Comparative population structure of cavity-nesting sea ducks: The Auk, v. 131, no. 2, p. 195-207. https://doi.org/10.1642/AUK-13-071.1.

Pearce, J.M., Mallory, L., and Metz, K., 2015, Common Merganser (Mergus merganser), version 2.0, in Poole, A.F., ed., The Birds of North America: Cornell Lab of Ornithology, Ithaca, NY, USA, accessed July 2, 2019, at: https://birdsna.org/Species-

Account/bna/species/commer/introduction

Peters, J.L., Bolender, K.A., and Pearce, J.M., 2012, Behavioural vs. molecular sources of conflict between nuclear and mitochondrial DNA-The role of male-biased dispersal in a Holarctic sea duck: Molecular Ecology, v. 21, no. 14, p. 3562-3575. https://doi.org/10.1111/j.1365-294X.2012.05612.x.

Petersen, M.R., and Flint, P.L., 2002, Structure of Pacific common eiders breeding in Alaska: The Condor, v. 104, no. 4, p. 780-787. https://doi.org/10.1093/condor/104.4.780.

Petersen, M.R., McCaffery, B.J., and Flint, P.L., 2003, Post-breeding distribution of long-tailed ducks Clangula hyemalis from the Yukon-Kuskokwim Delta, Alaska: Waterbirds, v. 54, p. 103-113.

Petersen, M.R., and Savard, J.-P.L., 2015, Variation in migration strategies of North American sea ducks, in Savard, J.-P.L., Derksen, D.V., Esler, D., and Eadie, J.M., eds., Ecology and Conservation of North American Sea Ducks-Studies in Avian Biology v. 46, p. 267-304.

Petersen, M.R., Byrd, G.V., Sonsthagen, S.A., and Sexson, M.G., 2015, Re-colonization by common eiders Somateria mollissima in the Aleutian Archipelago following removal of introduced arctic foxes Vulpes lagopus: Journal of Avian Biology, v. 46, no. 5, p. 538-549. https://doi.org/10.1111/jav.00626.

Phillips, L.M., Powell, A.N., and Rexstad, E.A., 2006, Large-scale movements and habitat characteristics of king eiders throughout the nonbreeding period: The Condor, v. 108, no. 4, p. 887-900. https://doi.org/10.1093/condor/108.4.887.

Powell, A.N., and Suydam, R.S., 2012, King eider (Somateria spectabilis), version 2.0., in Poole, A.F., ed., The Birds of North America: Cornell Lab of Ornithology, Ithaca, NY, USA, accessed July 2, 2019, at: https://birdsna.org/Species-Account/bna/species/kineid/introduction

Robert, M., Mittelhauser, G.H., Jobin, B., Fitzgerald, G., and Lamothe, P., 2008, New insights on harlequin duck population structure in eastern North America as revealed by satellite telemetry: Waterbirds, v. 31, p. 159-172.

Robertson, G.J., and Goudie, R.I., 1999, Harlequin duck (Histrionicus histrionicus), version 2.0., in Poole, A.F., Gill, F.B., eds., The Birds of North America: Cornell Lab of Ornithology, Ithaca, NY, USA, accessed July 2, 2019, at: https://birdsna.org/SpeciesAccount/bna/species/kineid/introduction

Robertson, G.J., and Savard, J.L., J-P.L., 2002, Long-tailed duck (Clangula hyemalis), version 2.0., in Poole, A.F., and Gill, F.B., eds., The Birds of North America: Cornell Lab of Ornithology, Ithaca, NY, USA, accessed July 2, 2019, at: https://birdsna.org/SpeciesAccount/bna/species/lotduc/introduction

Rodewald, P., 2015, The Birds of North America. Cornell Laboratory of Ornithology, Ithaca, NY, accessed May 9, 2019, at: https://birdsna.org

Rosenberg, D.H., Petrula, M.J., and Hill, D.D., 2019a, Using satellite telemetry to monitor movements of surf scoters (Melanitta perspicillata) captured in Prince William Sound, Alaska. Exxon Valdez Oil Spill Restoration Project Final Report (Restoration Project 00273 Vol. 1), 
Exxon Valdez Oil Spill Trustee Council, Anchorage, Alaska, accessed May 9, 2019, at: http://www.evostc.state.ak.us/Store/FinalReports/2000-00273-Final.pdf

Rosenberg, D.H., Petrula, M.J., and Hill, D.D., 2019b, Seasonal movements of white-winged scoters (Melanitta fusca) from Prince William Sound, Alaska. Exxon Valdez Oil Spill Restoration Project Final Report (Restoration Project 00273 Vol. II), Exxon Valdez Oil Spill Trustee Council, Anchorage, Alaska, accessed May 9, 2019, at:

http://www.evostc.state.ak.us/Store/FinalReports/2000-00273-Final.pdf

Rothe, T.C., Padding, P.I., Naves, L.C., and Robertson, G.J., 2015, Harvest of sea ducks in North America, in Savard, J.-P.L., Derksen, D.V., Esler, D., and Eadie, J.M., eds., Ecology and Conservation of North American Sea Ducks-Studies in Avian Biology v. 46, p. 417-467.

Rushing, C.S., Ryder, T.B., Scarpignato, A.L., Saracco, J.F., and Marra, P.P., 2016, Using demographic attributes from long-term monitoring data to delineate natural population structure: Journal of Applied Ecology, v. 53, no. 2, p. 491-500. https://doi.org/10.1111/13652664.12579.

Savard, J.-P.L., Lesage, L., Gilliland, S.G., Gilchrist, G., and Giroux, J.-F., 2011, Molting, staging, and wintering locations of common eiders breeding in the Gyrfalcon Archipelago, Ungava Bay: Arctic, v. 64, no. 2, p. 197-206. https://doi.org/10.14430/arctic4099.

Savard, J.-P.L., and Robert, M., 2013, Relationships among breeding, molting and wintering areas of adult female Barrow's goldeneyes (Bucephala islandica) in eastern North America: Waterbirds, v. 36, no. 1, p. 34-42. https://doi.org/10.1675/063.036.0107.

Sea Duck Joint Venture, 2015, Atlantic and Great Lakes sea duck migration study. Progress report by the Sea Duck Joint Venture Partnership, June 2015, accessed July 9, 2019, at: http://seaduckjv.org/science-resources/atlantic-and-great-lakes-sea-duck-migration-study/

Sonsthagen, S.A., Talbot, S.L., and McCracken, K.G., 2007, Genetic characterization of common eiders breeding in the Yukon-Kuskokwim Delta, Alaska: The Condor, v. 109, no. 4, p. 878-893. https://doi.org/10.1093/condor/109.4.878.

Sonsthagen, S.A., Talbot, S.L., Lanctot, R.B., Scribner, K.T., and McCracken, K.G., 2009, Hierarchical spatial genetic structure of Common Eiders (Somateria mollissima) breeding along a migratory corridor: The Auk, v. 126, no. 4, p. 744-754. https://doi.org/10.1525/auk.2009.08224.

Sonsthagen, S.A., Talbot, S.L., Lanctot, R.B., and McCracken, K.G., 2010, Do waterfowl nest in kin groups? Microgeographic structure in a philopatric seaduck: Molecular Ecology, v. 19, p. 647-657. https://doi.org/10.1111/j.1365-294X.2009.04495.X.

Sonsthagen, S.A., Talbot, S.L., Scribner, K.T., and McCracken, K.G., 2011, Multilocus phylogeography and population structure of common eiders breeding in North America and Scandinavia: Journal of Biogeography, v. 38, no. 7, p. 1368-1380. https://doi.org/10.1111/j.1365-2699.2011.02492.x.

Sonsthagen, S.A., Talbot, S.L., Wilson, R.E., Petersen, M.R., and McCracken, K.G., 2013, Genetic structure and asymmetrical gene flow in Common Eiders breeding on the Aleutian Islands, Alaska, prior to fox eradication: The Condor, v. 115, p. 28-39. https://doi.org/10.1525/cond.2012.110054.

Sonsthagen, S.A., Wilson, R.E., Lavretsky, P., and Talbot, S.L., 2019, Coast to coast: high genomic connectivity in North American scoters. Ecology and Evolution, https://doi.org/10.1002/ece3.5297.

Swoboda, C.J., 2007, Population delineation and wintering ground influence on vital rates of white-winged scoters. M.Sc. thesis, Department of Biology, University of Saskatchewan 
Saskatoon, accessed May 9, 2019, at: https:/harvest.usask.ca/handle/10388/etd-05022007145956

Thomas, P.W., Mittlehauser, G.H., Chubbs, T.E., Trimper, P.G., and Goudie, R.I., 2008, Movements of harlequin ducks in eastern North America: Waterbirds, v. 31, p. 188-193.

U.S. Geological Survey Bird Banding Laboratory, 2018, North American bird banding and band encounter data set. Patuxent Wildlife Research Center, Laurel, MD., accessed September 14, 2018.

U.S. Geological Survey Alaska Science Center, 2019, USGS Alaska Science Center wildlife tracking data collection (ver 1.0, July 2019): U.S. Geological Survey data release https://doi.org/10.5066/P9VYSWEH

Wikelski, M., and Kays, R., 2019, Movebank: archive, analysis and sharing of animal movement data. Hosted by the Max Planck Institute for Ornithology, accessed May 9, 2019, at: www.movebank.org

Wilson, R.E., Gust, J.R., Petersen, M.R., and Talbot, S.L., 2016, Spatial genetic structure of Long-tailed Ducks (Clangula hyemalis) among Alaskan, Canadian, and Russian breeding populations: Arctic, v. 69, no. 1, p. 65-78. https://doi.org/10.14430/arctic4548. 
Publishing support provided by the U.S. Geological Survey Science Publishing Network, Tacoma Publishing Service Center

For more information concerning the research in this report, contact the Director, Alaska Science Center

U.S. Geological Survey

4210 University Drive

Anchorage, Alaska 99508

https://www.usgs.gov/centers/asc/ 


\section{㞭}



